\title{
Concentrations of Selected Trace Elements in Fish Tissue and Streambed Sediment in the Clark Fork-Pend Oreille and Spokane River Basins, Washington, Idaho, and Montana, 1998
}

Water-Resources Investigations Report 00-4159

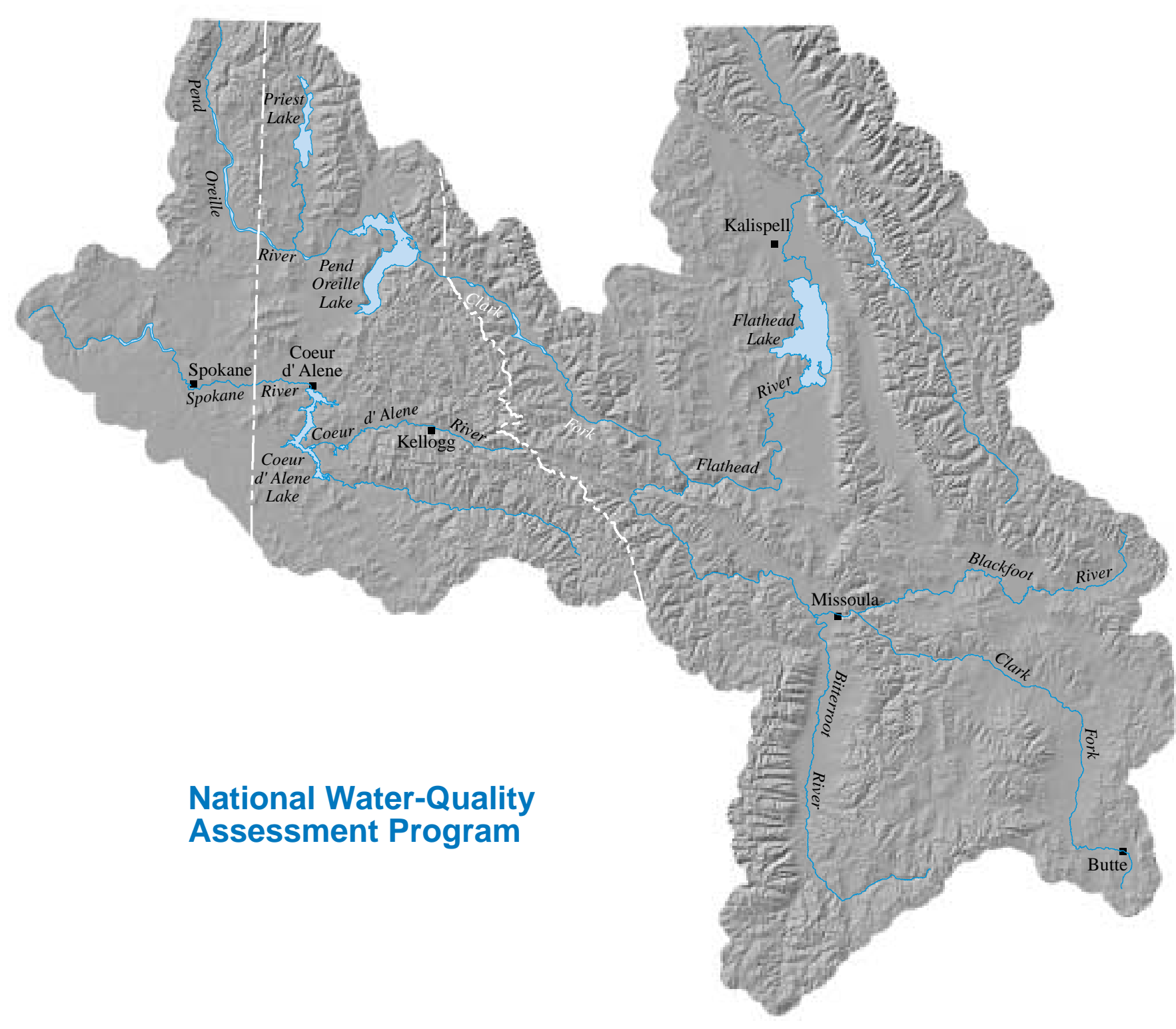



U.S. Department of the Interior

U.S. Geological Survey

\section{Concentrations of Selected Trace Elements in Fish Tissue and Streambed Sediment in the Clark Fork-Pend Oreille and Spokane River Basins, Washington, Idaho, and Montana, 1998}

By T.R. Maret and K.D. Skinner

Water-Resources Investigations Report 00-4159

National Water-Quality Assessment Program

Boise, Idaho

2000 


\section{U.S. DEPARTMENT OF THE INTERIOR}

BRUCE BABBITT, Secretary

\section{U.S. GEOLOGICAL SURVEY}

Charles G. Groat, Director

Any use of firm, trade, and brand names in this report is for identification purposes only and does not constitute endorsement by the U.S. Government.

Additional information can be obtained from:

Copies of this report can be purchased from:

District Chief

U.S. Geological Survey

230 Collins Road

Boise, ID 83702-4520

U.S. Geological Survey

Information Services

Box 25286

http://idaho.usgs.gov

Federal Center

Denver, CO 80225

e-mail: infoservices@usgs.gov

Information regarding the National Water-Quality Assessment (NAWQA) Program is available on the Internet via the World Wide Web. You may connect to the NAWQA Home Pages using the Universal Resource Locator (URL) at:

http://wwwrvares.er.usgs.gov/nawqa/nawqa_home.html

or

http://montana.usgs.gov/nrok/nrokpage.html 


\section{FOREWORD}

The mission of the U.S. Geological Survey (USGS) is to assess the quantity and quality of the earth resources of the Nation and to provide information that will assist resource managers and policymakers at Federal, State, and local levels in making sound decisions. Assessment of water-quality conditions and trends is an important part of this overall mission.

One of the greatest challenges faced by waterresources scientists is acquiring reliable information that will guide the use and protection of the Nation's water resources. That challenge is being addressed by Federal, State, interstate, and local water-resource agencies and by many academic institutions. These organizations are collecting water-quality data for a host of purposes that include: compliance with permits and water-supply standards; development of remediation plans for a specific contamination problem; operational decisions on industrial, wastewater, or watersupply facilities; and research on factors that affect water quality. An additional need for water-quality information is to provide a basis on which regionaland national-level policy decisions can be based. Wise decisions must be based on sound information. As a society we need to know whether certain types of water-quality problems are isolated or ubiquitous, whether there are significant differences in conditions among regions, whether the conditions are changing over time, and why these conditions change from place to place and over time. The information can be used to help determine the efficacy of existing water-quality policies and to help analysts determine the need for and likely consequence of new policies.

To address these needs, the Congress appropriated funds in 1986 for the USGS to begin a pilot program in seven project areas to develop and refine the National Water-Quality Assessment (NAWQA) Program. In 1991, the USGS began full implementation of the program. The NAWQA Program builds upon an existing base of water-quality studies of the USGS, as well as those of other Federal, State, and local agencies. The objectives of the NAWQA Program are to:
-Describe current water-quality conditions for a large part of the Nation's freshwater streams, rivers, and aquifers.

-Describe how water quality is changing over time.

-Improve understanding of the primary natural and human factors that affect water-quality conditions.

This information will help support the development and evaluation of management, regulatory, and monitoring decisions by other Federal, State, and local agencies to protect, use, and enhance water resources.

The goals of the NAWQA Program are being achieved through ongoing and proposed investigations of 59 of the Nation's most important river basins and aquifer systems, which are referred to as study units. These study units are distributed throughout the Nation and cover a diversity of hydrogeologic settings. More than two-thirds of the Nation's freshwater use occurs within the 59 study units and more than two-thirds of the people served by public water-supply systems live within their boundaries.

National synthesis of data analysis, based on aggregation of comparable information obtained from the study units, is a major component of the program. This effort focuses on selected water-quality topics using nationally consistent information. Comparative studies will explain differences and similarities in observed water-quality conditions among study areas and will identify changes and trends and their causes. The first topics addressed by the national synthesis are pesticides, nutrients, volatile organic compounds, and aquatic biology. Discussions on these and other waterquality topics will be published in periodic summaries of the quality of the Nation's ground and surface water as the information becomes available.

This report is an element of the comprehensive body of information developed as part of the NAWQA Program. The program depends heavily on the advice, cooperation, and information from many Federal, State, interstate, Tribal, and local agencies and the public. The assistance and suggestions of all are greatly appreciated.

Robert M. Hirsch Chief Hydrologist 



\section{CONTENTS}

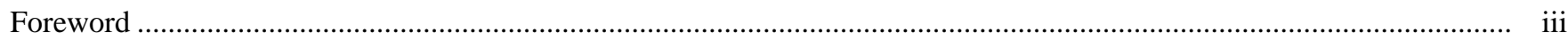

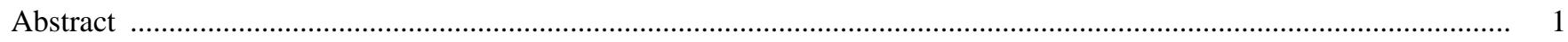

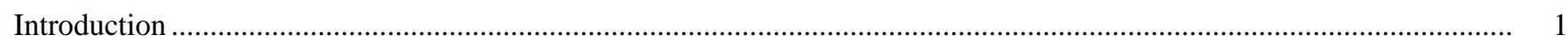

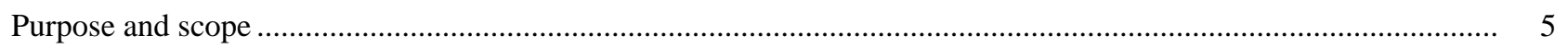

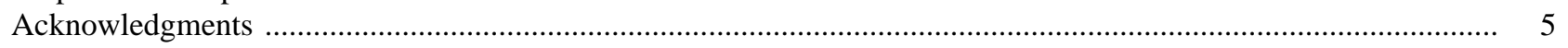

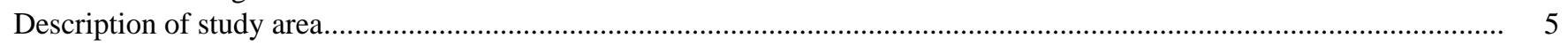

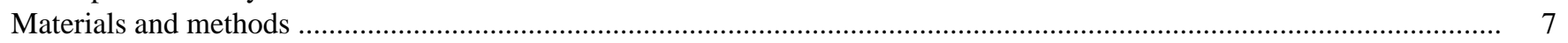

Sample collection, preparation, and analysis ..........................................................................................

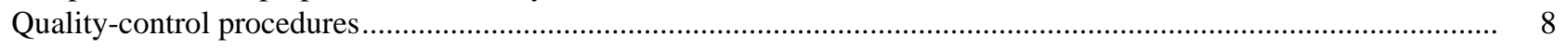

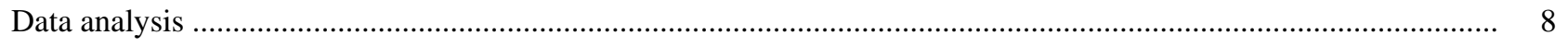

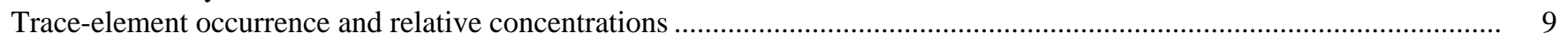

Trace-element concentrations in bed sediment and fish tissue ............................................................................ 11

Trace-element concentrations reported in other studies and guidelines............................................................... 11

Relations among trace-element concentrations, land use, and geology ..................................................................... 16

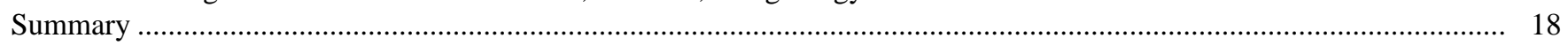

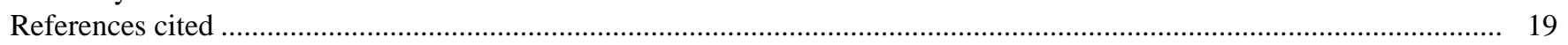

Appendix A. Hard-rock mining activities in the Northern Rockies Intermontane Basins study area and within a

250-meter buffer area along perennial streams in each subbasin ............................................................................. 25

Appendix B. Species, sizes, and tissue types of fish collected in the Northern Rockies Intermontane Basins study area, 1998

\section{FIGURES}

1. Map showing sampling site locations, production mines, and significant mineral deposits, Northern

Rockies Intermontane Basins study area

2. Graph showing densities of significant deposits in the 250-meter stream buffer and production mines upstream from each sampling site, Northern Rockies Intermontane Basins study area.....

3. Graphs showing trace-element concentrations in bed sediment and fish tissue (livers and fillets) at all sampling sites in the Northern Rockies Intermontane Basins study area

4. Boxplots showing distribution of ratios of trace-element concentrations in fish tissue (livers and fillets) to concentrations in bed sediment, Northern Rockies Intermontane Basins study area

5. Graph showing relations between production mine density and sum of trace-element concentrations in bed sediment, Northern Rockies Intermontane Basins study area

\section{TABLES}

1. Sampling sites and selected site and subbasin characteristics, Northern Rockies Intermontane Basins study area, 1998

2. Minimum reporting levels and trace-element concentrations in bed sediment and fish tissue, Northern Rockies Intermontane Basins study area ..

3. Comparison among various trace-element guidelines and concentrations detected in bed sediment and fish tissue, Northern Rockies Intermontane Basins study area.

Spearman's correlation coefficients for production mine densities, significant deposit densities, and traceelement concentrations in fish tissue (livers and fillets) and bed sediment, Northern Rockies Intermontane Basins study area. 
CONVERSION FACTORS AND OTHER ABBREVIATED UNITS

\begin{tabular}{rll}
\hline Multiply & By & To obtain \\
\hline centimeter $(\mathrm{cm})$ & 0.3937 & inch \\
gram $(\mathrm{g})$ & 0.03527 & ounce, avoirdupois \\
hectare $(\mathrm{ha})$ & 2.471 & acre \\
kilogram $(\mathrm{kg})$ & 2.205 & pound, avoirdupois \\
kilometer $(\mathrm{km})$ & 0.6214 & mile \\
meter $(\mathrm{m})$ & 3.281 & foot \\
metric ton & 1.102 & ton, short $(2,000$ pounds $)$ \\
millimeter $(\mathrm{mm})$ & 0.03937 & inch \\
square kilometer $\left(\mathrm{km}^{2}\right)$ & 0.3861 & square mile \\
\hline
\end{tabular}

Temperature in degrees Celsius $\left({ }^{\circ} \mathrm{C}\right)$ can be converted to degrees Fahrenheit $\left({ }^{\circ} \mathrm{F}\right)$ as follows:

${ }^{\circ} \mathrm{F}=(1.8)\left({ }^{\circ} \mathrm{C}\right)+32$

Other abbreviated units:

$\mu \mathrm{g} / \mathrm{g}$ microgram per gram

$\mu \mathrm{g} / \mathrm{L} \quad$ microgram per liter 


\title{
Concentrations of Selected Trace Elements in Fish Tissue and Streambed Sediment in the Clark Fork-Pend Oreille and Spokane River Basins, Washington, Idaho, and Montana, 1998
}

\author{
By T.R. Maret and K.D. Skinner
}

\section{ABSTRACT}

Fish tissue and bed sediment samples were collected from 16 stream sites in the Northern Rockies Intermontane Basins study area in 1998 as part of the U.S. Geological Survey National WaterQuality Assessment Program. Bed sediment samples were analyzed for 45 trace elements, and fish livers and sportfish fillets were analyzed for 22 elements to characterize the occurrence and distribution of these elements in relation to stream characteristics and land use activities. Nine trace elements of environmental concern-arsenic, cadmium, chromium, copper, lead, mercury, nickel, selenium, and zinc-were detected in bed sediment, but not all of these elements were detected in fish tissue. Trace-element concentrations were highest in bed sediment samples collected at sites downstream from significant natural mineral deposits and (or) mining activities. Arsenic, cadmium, copper, lead, mercury, and zinc in bed sediment at some sites were elevated relative to national median concentrations, and some concentrations were at levels that can adversely affect aquatic biota. Although trace-element concentrations in bed sediment exceeded various guidelines, no concentrations in sportfish fillets exceeded U.S. Environmental Protection Agency screening values for the protection of human health. Correlations between most trace-element concentrations in bed sediment and fish tissue (liver and fillet) were not significant $(r< \pm 0.50, p>0.05)$. Concentrations of arsenic, cadmium, copper, lead, mercury, nickel, selenium, and zinc in bed sediment were significantly correlated ( $\mathrm{r}=0.53$ to $0.88, \mathrm{p}<0.05$ ) with natural mineral deposits and mining activities, but concentrations in fish tissue generally were not correlated with these measures. Regression analysis between mine density and the sum of trace-element concentrations in bed sediment identified two statistically significant relations $\left(r^{2}=0.95\right.$ and $\left.0.99, \mathrm{p}<0.001\right)$ that corresponded to trace-element enrichment categories. These strong relations warrant further study using mine density as an explanatory variable to predict trace-element concentrations in bed sediment.

\section{INTRODUCTION}

The U.S. Geological Survey (USGS) National Water-Quality Assessment (NAWQA) Program is a perennial program designed to produce a comprehensive assessment of the quality of the Nation's stream and aquifer resources (Hirsch and others, 1988; Leahy and others, 1990). Investigations in more than 50 NAWQA study units use an integrated approach to assess the status and trends of water quality in major river basins of the Nation (Gurtz, 1994). This assessment consists of the collection of chemical, physical, and biological data at sites representing a wide range of water-quality conditions. One component of this integrated assessment of water quality is examination of the occurrence and distribution of trace elements in biological tissue and bed sediments on a basinwide scale.

This report presents results of trace-element analyses of fish tissue and associated bed sediments collected in 1998 in the Northern Rockies Intermontane Basins (NROK) study area. Data were collected at sites representing a gradient of stream sizes, areas of natural mineral deposits, and areas affected by mining activi- 


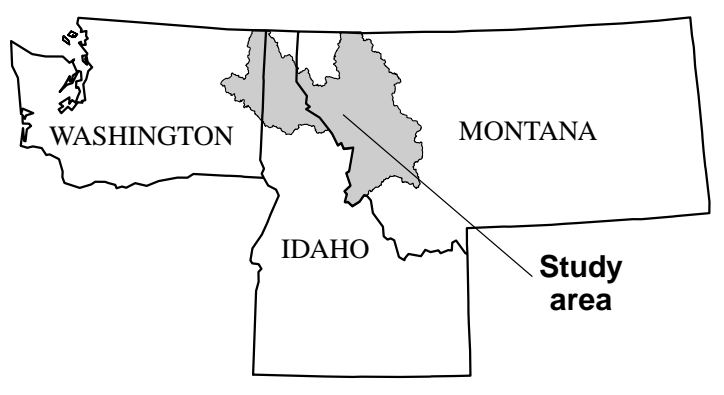

Base from U.S. Geological Survey digital data, Hydrologic unit maps, 1:100,000, 1994; Rivers and Streams, 1:250,000, 1994; Albers Equal-Area projection Standard parallels $46^{\circ} 00^{\prime}, 48^{\circ} 30^{\prime}$, and $-115^{\circ} 00^{\prime}, 45^{\circ} 00^{\prime}$

No false easting or false northing

$$
49
$$

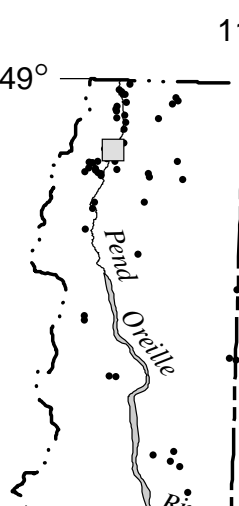

$117^{\circ}$

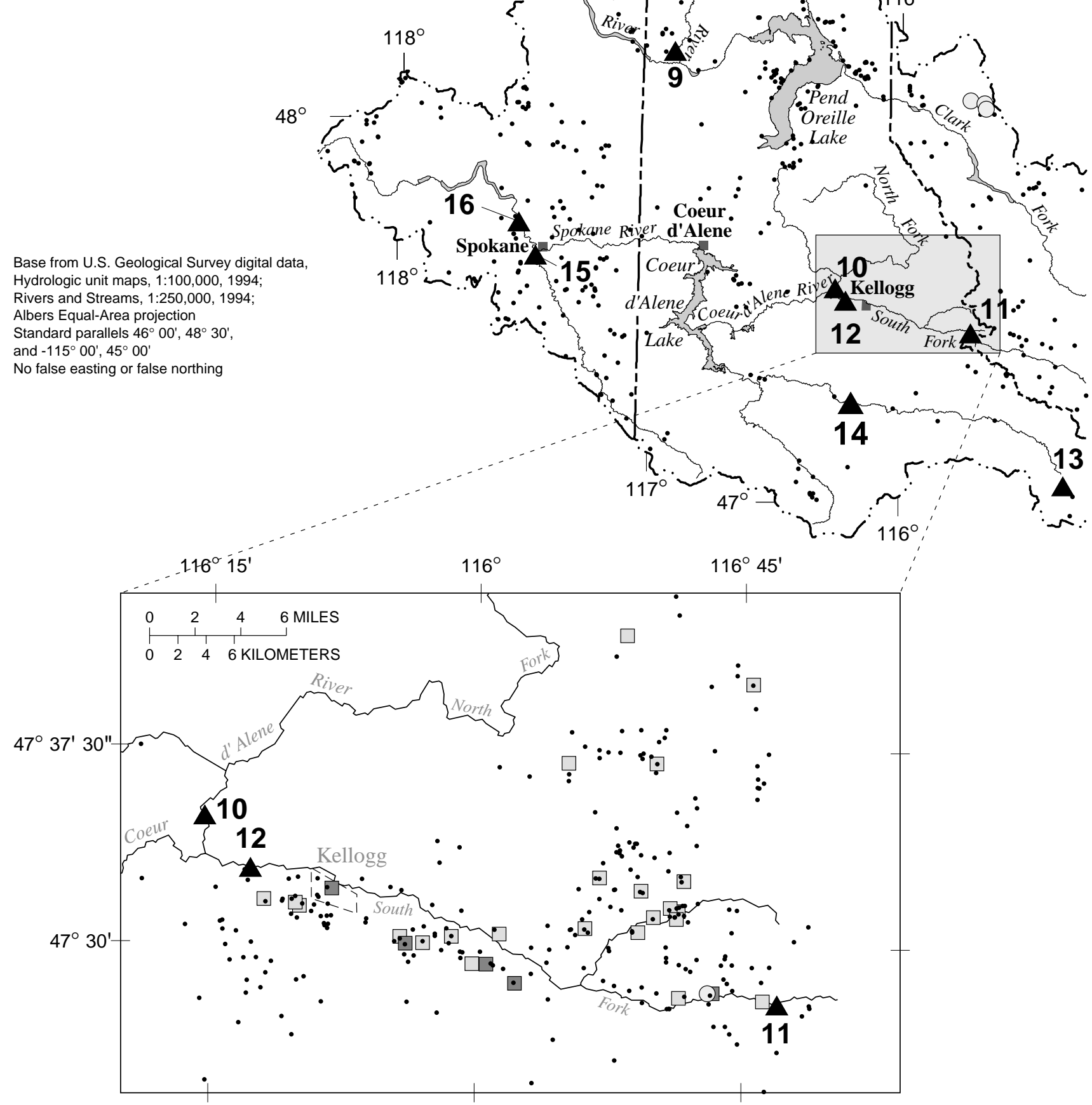

Figure 1. Sampling site locations, production mines, and significant mineral deposits, Northern Rockies Intermontane 


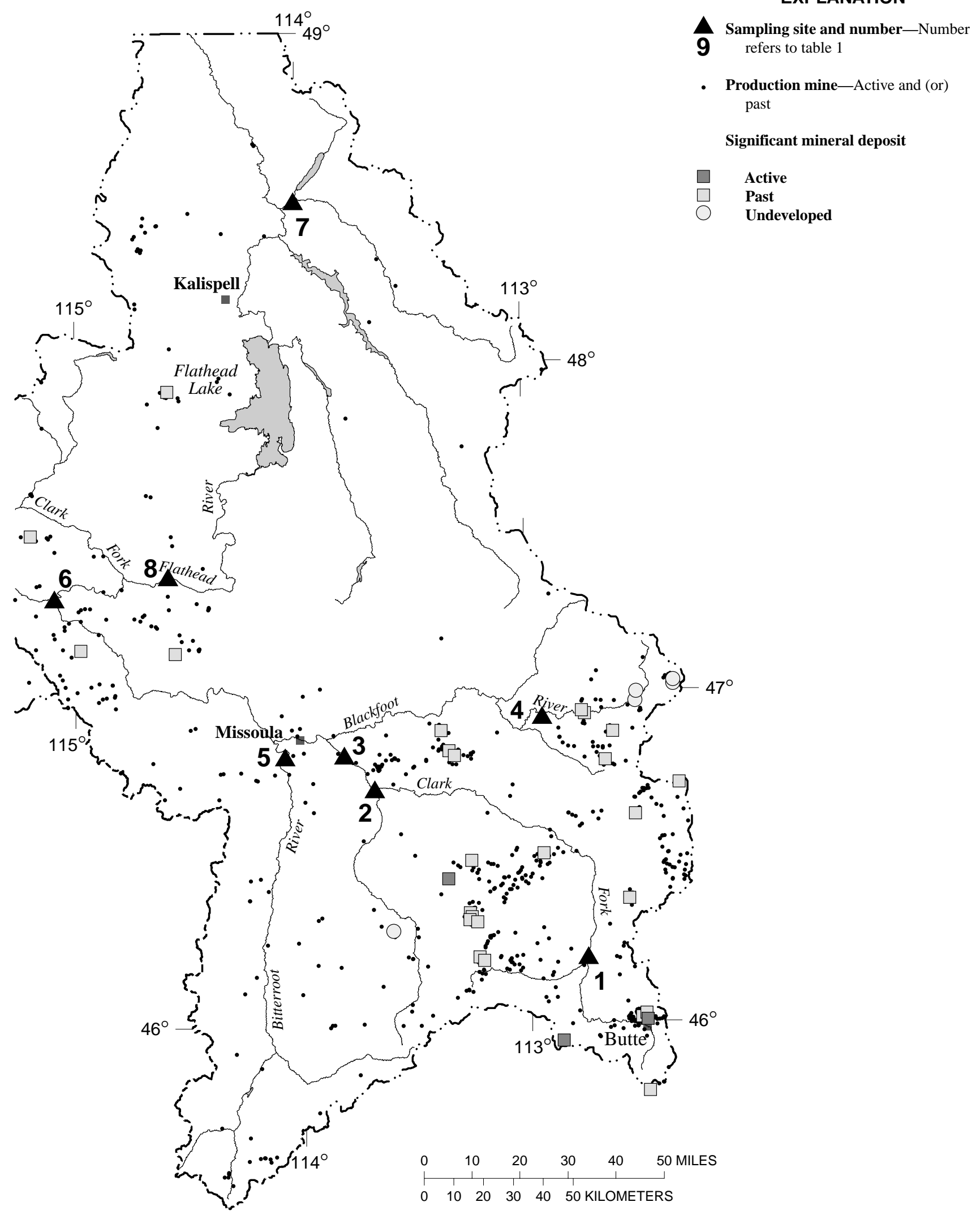

Basins study area. 
ties. Results are summarized for nine elements that are of environmental concern-arsenic, cadmium, chromium, copper, lead, mercury, nickel, selenium, and zinc (hereafter abbreviated $\mathrm{As}, \mathrm{Cd}, \mathrm{Cr}, \mathrm{Cu}, \mathrm{Pb}, \mathrm{Hg}, \mathrm{Ni}$, $\mathrm{Se}$, and $\mathrm{Zn}$, respectively). All nine elements are on the U.S. Environmental Protection Agency's (USEPA) list of 126 Priority Pollutants (U.S. Environmental Protection Agency, 1994).

Trace elements in the aquatic environment occur naturally from weathering of rocks and mineral soils and from human sources such as the burning of fossil fuels, industrial discharges, automobile emissions, mining, and agricultural pesticides and fertilizers. Historical and current mining practices are believed to affect the quality of streams and aquifers in the NROK study area (fig. 1) (Hornberger and others, 1997; Tornes, 1997; Beckwith, 1998). Past mining activities have resulted in Superfund investigations and remediations along the upper Clark Fork and South Fork Coeur d'Alene River. The two largest Superfund sites in the Nation are located in the study area-the Anaconda Company Smelter near Butte, Montana, and the Bunker Hill Smelter near Kellogg, Idaho (Doppelt and others, 1993). In addition, the U.S. Department of the Interior is currently conducting Natural Resource Damage Assessments in and around these Superfund complexes (Beckwith, 1998).

Many trace elements, especially $\mathrm{Cu}, \mathrm{Se}$, and $\mathrm{Zn}$, are essential to animal and plant nutrition but can be toxic in high concentrations (U.S. Department of the Interior, 1998). $\mathrm{As}, \mathrm{Cd}, \mathrm{Cu}, \mathrm{Pb}, \mathrm{Hg}$, $\mathrm{Se}$, and $\mathrm{Zn}$ are some of the more notable elements found to be toxic to aquatic life (Eisler, 1985, 1987, 1988; U.S. Department of the Interior, 1998). Aquatic organisms have developed mechanisms to regulate internal concentrations of certain trace elements in tissues or to mitigate their toxicity (Law, 1996). However, because of the slow rate of elimination, some of the more toxic trace elements, such as $\mathrm{Hg}, \mathrm{Cd}, \mathrm{Se}$, and $\mathrm{Pb}$, tend to bioaccumulate, and $\mathrm{Hg}$ may biomagnify in aquatic food chains (Eisler, 1985, 1988; Wiener and Spry, 1996; U.S. Department of the Interior, 1998). As a result, trace-element concentrations in tissues of aquatic species generally increase with increasing age, body size, and trophic status (Wiener and Spry, 1996; Park and Curtis, 1997).

Trace-element concentrations are generally higher in bed sediments and tissue than in water (Rainbow, 1996). Trace-element concentrations in sediment can be at least three orders of magnitude greater than the same elements in aqueous phases because trace ele- ments often sorb to particle surfaces (Horowitz, 1991). Elevated trace-element concentrations in fine-grained bed sediment and tissue of fish in streams near mining activities in Colorado have been documented (Heiny and Tate, 1997; Deacon and Driver, 1999).

Concentrations of contaminants in tissue provide a time-integrated assessment of contaminants and a better understanding of the complexities of the fate, distribution, and effects of various contaminants (Crawford and Luoma, 1993). Trace elements can be ingested with streambed sediment or suspended sediment in the water column by benthic organisms and can accumulate and move through the food chain. Fish are particularly good indicators of biologically available contaminants because environmental contaminants can accumulate in their bodies at higher concentrations than in surrounding water. Many trace elements concentrate in the viscera of fish such as the liver and kidneys (Crawford and Luoma, 1993). Notable exceptions include $\mathrm{Hg}$, which tends to concentrate to higher levels in muscle (Goldstein and others, 1996), and $\mathrm{Pb}$, which preferentially sequesters in active calcification areas such as scales, fin rays, vertebrae, and opercula (Sorensen, 1991). The concentrations of trace elements in liver and muscle also may vary, depending on a number of factors such as the chemical properties of the element and the species of fish.

A summary of tissue contaminant information by Maret and Dutton (1999) indicated that concentrations of $\mathrm{Cd}, \mathrm{Cu}, \mathrm{Pb}, \mathrm{Hg}$, and $\mathrm{Zn}$ in fish and macroinvertebrates collected in and around mining sites in the study area typically were elevated, compared with background concentrations. Some concentrations in tissue exceeded State and Federal guidelines for protection of human health and (or) wildlife. Maret and Dutton also concluded there was a need for further study to characterize the severity of contamination in fish tissue. As of 1998, no fish consumption advisories or fishing restrictions on any rivers within the study area had been issued as a result of elevated trace elements. This was due in part to the lack of sportfish tissue data collected for the assessment of human health risk (Maret and Dutton, 1999). According to the Natural Resource Defense Council (1998), fish tissue contaminants are a serious national health concern that has not been adequately addressed by current pollution abatement and monitoring programs. 


\section{Purpose and Scope}

The purpose of this report is to summarize the concentrations and distribution of selected trace elements in fish tissue and bed sediment in the NROK study area and provide information to determine whether concentrations are at levels of concern to human health and aquatic life. Relations among trace-element concentrations in fish tissue and bed sediment and basinwide land use, geology, and mining activities also are evaluated. The findings of this report will provide a better understanding of trace-element concentrations in aquatic environments that are highly enriched with trace elements.

\section{Acknowledgments}

Numerous individuals from the USGS assisted in collecting and processing data during the course of the study - John Baker, Dorothy Barnett, Mike Beckwith, Craig Bowers, DeAnn Dutton, Kari Finley, Steve Goodbred, Keith Hein, Ivan James, Doug Ott, Terry Short, and Lan Tornes. Colleague reviews by Rod Deweese, Terry Short, and Lan Tornes improved the quality of the manuscript.

\section{DESCRIPTION OF STUDY AREA}

The NROK study area (fig. 1) is an $81,585-\mathrm{km}^{2}$ area in western Montana, northern Idaho, and northeastern Washington. The study area is composed of two major river basins: the Clark Fork-Pend Oreille River Basin, which encompasses about $64,491 \mathrm{~km}^{2}$, and the Spokane River Basin, which encompasses about 17,094 km² (Maret and Dutton, 1999).

The study area includes four ecoregions: Northern Rockies (72 percent); Montana Valley and Foothill Prairies (16 percent); Canadian Rockies (9 percent); and Columbia Plateau (3 percent) (Maret and Dutton, 1999). The Northern Rockies and Canadian Rockies ecoregions characterize the high-elevation, mountainous parts of the study area. These ecoregions consist primarily of coniferous forests, and the predominant land uses are timber, mining, and recreation. The Montana Valley and Foothill Prairies and Columbia Plateau ecoregions represent lower elevations characterized by flatlands and rolling hills vegetated with grasses and, in drier areas, sagebrush. Land use in these lower eleva- tion ecoregions is primarily dryland and irrigated cropland and grazing.

The population of the study area in 1990 was about 725,000: 350,000 in Washington; 255,000 in Montana; and 120,000 in Idaho (Tornes, 1997). Land ownership is about 56 percent public, 37 percent private, and 7 percent Tribal.

The study area has a complex geologic history of sedimentation, compressional deformation, igneous activity, and, most recently, extensional block faulting (Kendy and Tresch, 1996). Because of the extent of mineralized areas in the NROK, natural conditions can affect trace-element concentrations in streams. Table 1 summarizes the major geologic formations in the study area.

Streams in the study area are predominantly coldwater, and snowmelt runoff during April to July represents the main source of surface water and ground water (Kendy and Tresch, 1996). Upland forest and lower elevation rangeland streams typically have coarse-grained substrates (gravel and cobble), high gradients (greater than 1.0 percent), well-defined rifflepool habitats, and sparse macrophyte growth. Large rivers and streams at lower elevations typically have finer grained substrates and lower gradients.

The quality of surface and ground water in both the Spokane River and Clark Fork-Pend Oreille Basins has been adversely affected by mining activities. At least 1,350 active and abandoned hard-rock mines of various sizes are located in the study area (fig. 1, appendix A). Historically, metal extraction and processing were relatively inefficient, yielding large volumes of metal-rich tailings that were deposited to nearby streams. Many of these mines were located near streams (see fig. 1, enlargement of the South Fork Coeur d'Alene River Basin). Mine tailings in the study area typically contain elevated levels of the trace elements $\mathrm{As}, \mathrm{Cd}, \mathrm{Cu}, \mathrm{Pb}$, $\mathrm{Hg}$, and $\mathrm{Zn}$. These tailings and mines continue to provide a source of trace elements to streams, lakes, and reservoirs as streams meander through and erode tailings deposits and transport them downstream. Mine tailings entering the South Fork Coeur d'Alene River have been transported and deposited along the river channel and flood plain into Coeur d'Alene Lake and out of the lake into the Spokane River. Horowitz and others (1995) estimated that 85 percent of the Coeur d'Alene Lake bed is enriched with trace elements. The USEPA (1997) National Sediment Inventory identified the Coeur d'Alene River and Lake as "areas of proba- 
Table 1. Sampling sites and selected site and subbasin characteristics, Northern Rockies Intermontane Basins study area, 1998

[No., number; fig., figure; $\mathrm{km}^{2}$, square kilometers; m, meters; MT, Montana; ID, Idaho; WA, Washington; F, forest land; R, rangeland; A, agricultural land; U, urban and (or) residential land; OLU, other, including barren rock, tundra, water, or transitional; IR, intrusive rock; ER, extrusive rock; AD, alluvial deposits; SD, sedimentary rock; MR, metasedimentary rock, undifferentiated; GD, glacial deposits; MTR, metamorphic rock; CC, carbonate and clastic rock; OGT, other, includes lakes and undifferentiated deposits ]

\begin{tabular}{|c|c|c|c|c|c|}
\hline Sampling site name & $\begin{array}{c}\text { Site } \\
\text { No. } \\
\text { (fig. 1) }\end{array}$ & $\begin{array}{c}\text { Basin } \\
\text { area } \\
\left(\mathbf{k m}^{2}\right)\end{array}$ & $\begin{array}{l}\text { Elevation } \\
\quad(\mathrm{m})\end{array}$ & Percent land use & Percent geologic type ${ }^{1}$ \\
\hline Clark Fork near Galen, MT. . . . . . . . . & 1 & 1,729 & 1,447 & F 44, R 43, A 2, U 3, OLU 8 & $\begin{array}{l}\text { IR 32, ER 22, CC 12, AD 11, SD 10, } \\
\text { OGT } 2\end{array}$ \\
\hline Rock Creek near Clinton, MT. & 2 & 2,314 & 1,073 & F 81, R 16, OLU 3 & $\begin{array}{l}\text { MR 68, IR 13, SD 6, GD 6, CC 3, ER 2, } \\
\quad \text { AD } 2\end{array}$ \\
\hline Clark Fork at Turah Bridge near Bonner, MT. . & 3 & 9,520 & 1,012 & F 58, R 32, A 6, OLU 4 & $\begin{array}{l}\text { MR 29, CC 18, IR 14, ER 14, SD 13, AD 8, } \\
\text { GD 3, OGT } 1\end{array}$ \\
\hline Blackfoot River near Helmville, MT & 4 & 1,242 & 1,311 & F 89, R 5, A 3, OLU 3 & MR 66, GD 13, ER 10, AD 8, CC 1, OGT 2 \\
\hline Bitterroot River near Missoula, MT . . . . . . . . . . & 5 & 7,250 & 948 & F 72, R 13, A 9, OLU 6 & IR 48, MR 27, MTR 9, AD 6, SD 3, OGT 7 \\
\hline Clark Fork at St. Regis, MT . . . . . . . . . . . & 6 & 27,819 & 806 & F 72, R 18, A 6, OLU 4 & $\begin{array}{l}\text { MR 45, IR 18, AD 7, ER 7, SD 7, GD 5, } \\
\text { CC 7, MTR 2, OGT } 2\end{array}$ \\
\hline Middle Fork Flathead River near West Glacier, MT. . . . & 7 & 2,939 & 954 & F 71, R 15, OLU 14 & MR 69, CC 17, GD 10, AD 3, OGT 1 \\
\hline Flathead River at Perma, MT $^{2} \ldots \ldots \ldots \ldots \ldots \ldots$ & 8 & 21,787 & 753 & F 70, R 13, A 8, OLU 9 & MR 64, GD 23, CC 6, AD 4, OGT 3 \\
\hline Priest River near Priest River, ID $\ldots \ldots \ldots \ldots \ldots \ldots$ & 9 & 2,460 & 637 & F 93, R 2, OLU 5 & $\begin{array}{l}\text { IR 44, MR 24, AD 15, MTR 8, GD 4, } \\
\text { OGT } 5\end{array}$ \\
\hline North Fork Coeur d'Alene River at Enaville, ID . . . . . . & 10 & 2,325 & 640 & F 98, R 2 & MR 100 \\
\hline South Fork Coeur d'Alene River near Mullan, ID . . . . . & 11 & 18 & 1,100 & F 97, OLU 3 & MR 100 \\
\hline South Fork Coeur d'Alene River near Pinehurst, ID . . . & 12 & 738 & 668 & F 88, R 6, OLU 6 & MR 97, IR 1, OGT 2 \\
\hline St. Joe River at Red Ives Ranger Station, ID . . . . . . & 13 & 275 & 1,128 & F 91, R 8, OLU 1 & MR 100 \\
\hline 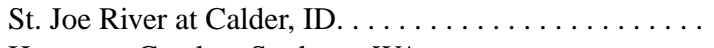 & 14 & 2,679 & 662 & F 93, R 7 & MR 79, MTR 17, IR 4 \\
\hline Hangman Creek at Spokane, WA . . . . . . . . . . & 15 & 1,785 & 523 & F 33, A 63, OLU 4 & ER 48, MR 44, MTR 5, AD 2, IR 1 \\
\hline \multicolumn{6}{|l|}{ Spokane River above 7 Mile Bridge near } \\
\hline 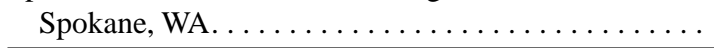 & 16 & 12,995 & 494 & F 78, R 3, A 14, U 3, OLU 2 & MR 65, ER 13, MTR 12, AD 6, IR 2, OGT 2 \\
\hline
\end{tabular}

\footnotetext{
${ }^{1}$ Geologic types taken from Tuck and others (1996).
}

${ }^{2}$ Includes portion of the basin in Canada 
ble concern for sediment contamination," the most severe contamination category in their assessment.

Andrews (1987) estimated that 91 million metric tons of tailings have been supplied to the headwaters of the Clark Fork during the period of mining from 1880 to 1982. Metal enrichment remains evident in the Clark Fork sediments and biota for more than $280 \mathrm{~km}$, from Butte to near Missoula, Mont. (Moore and Luoma, 1990). Elevated trace-element concentrations in the Clark Fork in Montana have caused fish kills and suppression of fish production (Phillips and Lipton, 1995). Juvenile trout also have shown reduced growth and survival as a result of ingesting macroinvertebrates from the Clark Fork, where trace-element concentrations are elevated (Farag and others, 1994; Woodward and others, 1994). Contrary to this, the USEPA's recent (1999) Ecological Risk Assessment has determined that these feeding studies are inconclusive and recommend further studies to evaluate trout growth and survival in the Clark Fork (D.S. Brown, U.S. Environmental Protection Agency, written commun., 2000).

\section{MATERIALS AND METHODS}

\section{Sample Collection, Preparation, and Analysis}

Trace elements in bottom sediment and fish tissue were sampled from 16 sites throughout the study area (table 1, fig. 1) at low-flow conditions during June to September 1998. Bed sediment and fish tissue were collected from the same 300- to 1,000-m reach at each site. Samples were collected in accordance with USGS NAWQA procedures (Meador and others, 1993; Shelton and Capel, 1994). Trace elements in tissue were analyzed by the USGS National Water Quality Laboratory in Arvada, Colo. (Hoffman, 1996). Trace elements in bed sediment were analyzed by the USGS Mineral Resources Laboratory in Lakewood, Colo. (Arbogast, 1990; Briggs and Meier, 1999).

The upper $2 \mathrm{~cm}$ of bed sediment was collected from undisturbed, continuously wetted, depositional zones by using a plastic scoop. Five to 10 subsamples of streambed sediment within the sampling reach were composited and sieved onsite at the <63-micron size fraction and submitted to the laboratory for analysis (Shelton and Capel, 1994). Because trace elements are not expected to significantly sorb to the $>63$-micron sediment particles, the smaller size fraction was chosen to normalize the size fraction and to maximize the con- centration of trace elements. Because the <63-micron size fraction, rather than bulk sediment, was analyzed, the likelihood of exceeding a guideline or screening value (SV) based on bulk sediment concentrations may be increased. A bed sediment sample also was collected and sieved to retain the $<2-\mathrm{mm}$ particle for particle-size analysis by the USGS laboratory in Vancouver, Wash.

Fish were collected using electrofishing techniques from all habitats within a reach (Meador and others, 1993). Four to 17 adult fish of the same species and of similar sizes were collected at each site. At most sites, livers and fillets were removed from different individuals of the same species and combined for a single composite sample. At a few sites, both liver and fillet samples were collected from the same individuals owing to low numbers of adult fish of similar size at those sites. Species collected included brook trout (Salvelinus fontinalis), brown trout (Salmo trutta), cutthroat trout (Oncorhynchus clarki), largescale sucker (Catostomus macrocheilus), mountain whitefish (Prosopium williamsoni), and rainbow trout (Oncorhynchus mykiss). Summary statistics about the fish sampled are provided in appendix B. Fish were identified, measured, examined for external anomalies, and processed indoors in a mobile laboratory to avoid contamination. Fish collected at all sites appeared in generally good health and external anomalies were seldom observed. Composite samples of livers and fillets were obtained from the fish collected at each site. Livers from each species were placed in plastic containers; fillets from sportfish were obtained by removing a fillet from one side of the body and removing the skin (U.S. Environmental Protection Agency, 1995). All samples were frozen onsite with dry ice. Further details on tissue sampling methods and preparation used in this study are included in a report by Crawford and Luoma (1993).

Fish tissue samples were prepared for trace-element analyses using a nitric acid digestion at $70^{\circ} \mathrm{C}$ followed by the addition of hydrogen peroxide to decompose biological material. The bed sediment samples were digested using a mixture of hydrochloric, nitric, perchloric, and hydrofluoric acids. The resultant solutions from tissue and bed sediment were evaporated to incipient dryness, reconstituted with 5 percent nitric acid, and filtered. Fish tissue extracts were analyzed by methods outlined in a report by Hoffman (1996) and included inductively coupled plasma-atomic emission spectrometry and inductively coupled plasma-mass spectrometry; $\mathrm{Hg}$ was analyzed by cold vapor-atomic adsorption spectrometry. Bed sediments were analyzed 
for most trace elements by using inductively coupled plasma-mass spectrometry (Briggs and Meier, 1999); Se was analyzed by continuous hydride generationatomic adsorption spectrometry and $\mathrm{Hg}$ by cold vaporatomic adsorption spectrometry (Arbogast, 1990).

\section{Quality-Control Procedures}

Field replicate samples were collected at three sites to determine environmental and sampling technique variability for bed sediment and (or) fish tissue. Triplicate samples of bed sediment to assess within-site variability were collected at sites 3 and 12 . Triplicate samples of livers were collected at site 3 , and duplicate samples of fillets were collected at site 7 (appendix B). Relative percent differences in trace-element concentrations among replicate sediment samples were greater than differences among replicate tissue samples. The differences among bed sediment replicates ranged from about 9 percent at site 3 to 107 percent at site 12. Differences were greatest at site 12 for $\mathrm{Cd}$ (107 percent), $\mathrm{Pb}$ (71 percent), and $\mathrm{Zn}$ (103 percent). The coefficients of variation among all elements detected in replicates of bed sediment ranged from 3 to 55 percent. Differences among triplicate liver samples at site 3 ranged from about 18 to 75 percent. The coefficients of variation among all elements detected in liver replicates ranged from 10 to 38 percent. Differences between duplicate fillet samples from the same fish at site 7 ranged from about 8 to 38 percent. Contrary to these findings, Bonn (1999) observed a greater difference in concentrations, ranging from 20 to 200 percent for similar elements, among replicate tissue samples than among bed sediment samples.

The large variability in concentrations among bed sediment field replicates may be due to where samples were collected. Replicates collected at mining-affected reaches (sites 3 and 12) exhibited higher concentrations of some trace elements relative to concentrations in samples from most other sites. Streams affected by mine-tailings deposits can exhibit variable mineral deposits along streambanks that reflect past mining practices and subsequent instream deposition. These replicate samples represent both spatial variability and the variability associated with collection and analysis of separate samples.

Laboratory quality control for bed sediment samples included analyses of a reference material (enriched soil) and an analytical replicate for each batch of sam- ples analyzed. Values for elements in reference material were within quality-assurance guidelines of \pm 3 standard deviations (Arbogast, 1990).

Laboratory quality control for fish tissue included analyses of blank samples, duplicate samples, and two standard reference materials (National Institute of Standards and Technology oyster tissue and bovine liver) for each batch of tissue samples. The NWQL reported values were within \pm 3 standard deviations of the reference material certified values (Arbogast, 1990).

\section{Data Analysis}

Forty-five and 22 trace elements were analyzed in bed sediment and fish tissue, respectively. A complete list of all elements and their concentrations can be found in the USGS National Water Information System data base. Nine of these elements that are of environmental concern- $\mathrm{As}, \mathrm{Cd}, \mathrm{Cr}, \mathrm{Cu}, \mathrm{Pb}, \mathrm{Hg}, \mathrm{Ni}, \mathrm{Se}$, and $\mathrm{Zn}$-were selected for discussion.

Matrices of bivariate correlations were constructed using SYSTAT (Wilkinson, 1998) to examine all possible combinations of responses and explanatory variables. Mean concentrations were used in the data analysis for replicate samples. Nondetections (below the minimum reporting level) were set to zero prior to analysis.

Trace-element concentrations in bed sediment were not normalized to organic carbon because no significant correlations $(p<0.05)$ were found between concentrations and percent organic carbon. Particle-size analysis prior to sieving determined that the bed sediment samples were composed predominantly of sand; the $<63$-micron particle-size fraction ranged from 3 to 40 percent for all samples. Organic carbon ranged from 0.7 to 4.9 percent for all bed sediment samples.

Spearman's rho was used as a measure of the degree of association between trace-element concentrations and landscape variables that included land use, geology, and mining activity. This statistic also was used to evaluate relations between concentrations in sediment and tissue samples. A Mann-Whitney test was used to test differences in median concentrations in fish liver and fillet samples.

Landscape variables upstream from each site were determined using a geographic information system (ArcView). Spatial coverages were obtained from the Interior Columbia Basin Ecosystem Management 
Project World Wide Web site (U.S. Forest Service and Bureau of Land Management, 1998).

Land use was modified from 1:250,000-scale digital data (U.S. Geological Survey, 1986) consisting of a level-II classification scheme at a 16-ha mapping resolution (Anderson and others, 1976). Geologic information was obtained from a report by Tuck and others (1996). Trace-element enrichment measures were determined for each basin to provide indicators of significant natural mineral deposits and human disturbance from mining. Production mines for each basin were located using the U.S. Bureau of Mines (1995) Minerals Availability System. Significant deposits are defined by Long and others (1998) as large, natural source areas that, prior to being mined, contained at least one of the following: 50,000 metric tons of copper, 2 metric tons of gold, 30,000 metric tons of lead, 85 metric tons of silver, or 50,000 metric tons of zinc. There are 66 significant deposits in the study area, and Long and others reported that these deposits accounted for more than 90 percent of past mine production of these elements. These deposits can be grouped into three mining categories - active (8 deposits), past (49 deposits), and undeveloped (9 deposits). Densities of mine category groups were determined for a $250-\mathrm{m}$ buffer area along each stream margin for all stream channels in each basin. Figure 2 summarizes the sample sites in relation to significant mineral deposits and production mines upstream from each site. Sites are grouped along the $\mathrm{x}$-axis on the basis of whether they have significant deposits. Sites 1, 3, 4, 6, 10, 12, and 16 are considered to be enriched with trace elements from these natural and human-caused sources relative to the other sample sites, whereas sites $2,5,7,8,9,11,13$, 14 , and 15 are unenriched with trace elements.

Analyses of bed sediment and liver tissue of fish collected from streams across the Nation during 199296 for the NAWQA Program were compared with analyses from this study (Rice, 1999; T. Short, U.S. Geological Survey, written commun., 1999). The USEPA SV (U.S. Environmental Protection Agency, 1995, 1997) for selected trace elements was used to evaluate edible tissue (fillets) and bed sediment concentrations. The Canadian Interim Sediment Quality Guidelines (ISQGs) were used to evaluate the severity of the traceelement contamination in bed sediment (Canadian Council of Ministers of the Environment, 1995). Guidelines used in this report refer to any SV, action level, or elevated level (85th percentile, determined from the NAWQA Program) useful for assessing contaminant concentrations.

\section{TRACE-ELEMENT OCCURRENCE AND RELATIVE CONCENTRATIONS}

All nine trace elements were detected in all bed sediment samples; however, only the essential trace elements $\mathrm{Cu}, \mathrm{Se}$, and $\mathrm{Zn}$ were detected in all fish tissue samples. $\mathrm{Hg}$, a nonessential trace element, was detected in 97 percent of the fish tissue samples. Similarly, the National Bioaccumulation Study detected $\mathrm{Hg}$ in 92 percent of the fish tissue samples collected primarily in 1987 at more than 300 locations nationwide (U.S. Environmental Protection Agency, 1992). Cr was detected in only 45 percent of the fish tissue samples. The frequency of detection for the nonessential trace elements $\mathrm{As}, \mathrm{Cd}, \mathrm{Hg}, \mathrm{Ni}$, and $\mathrm{Pb}$ in tissue ranged from 16 percent to 97 percent.

Median concentrations of $\mathrm{Cd}, \mathrm{Cu}, \mathrm{Se}$, and $\mathrm{Zn}$ were significantly higher in liver than in fillet tissue (table 2). Further analysis of seven liver and fillet samples from the same fish of five different trout species (see appendix B) resulted in similar significant differences in median concentrations of these four trace elements. Overall, median concentrations of $\mathrm{Cu}$ and $\mathrm{Zn}$ were an

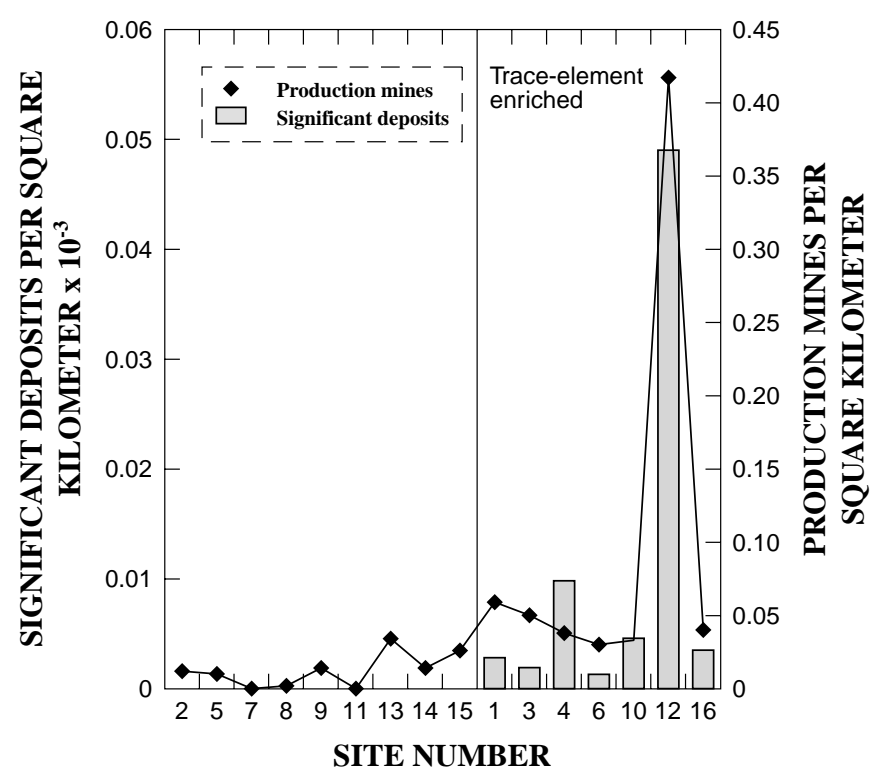

Figure 2. Densities of significant deposits in the 250-meter stream buffer and production mines upstream from each sampling site, Northern Rockies Intermontane Basins study area. (Site names shown in table 1; locations shown in figure 1). 
Table 2. Minimum reporting levels and trace-element concentrations in bed sediment and fish tissue, Northern Rockies Intermontane Basins study area

[Concentrations reported in micrograms per gram, dry weight; see appendix B for fish species analyzed; n, number of samples; <, less than]

\begin{tabular}{|c|c|c|c|c|c|c|c|c|}
\hline \multirow[b]{4}{*}{ Trace element } & \multirow{3}{*}{\multicolumn{2}{|c|}{$\begin{array}{c}\text { Minimum reporting } \\
\text { level }\end{array}$}} & \multicolumn{6}{|c|}{ Concentrations } \\
\hline & & & \multirow{2}{*}{\multicolumn{2}{|c|}{ Bed sediment $(n=16)$}} & \multicolumn{4}{|c|}{ Tissue } \\
\hline & & & & & \multicolumn{2}{|c|}{ Liver $(n=16)$} & \multicolumn{2}{|c|}{ Fillets $(n=15)$} \\
\hline & sediment & Tissue & Median & Range & Median & Range & Median & Range \\
\hline Arsenic $\ldots \ldots \ldots \ldots$ & 0.1 & 0.1 & 9.7 & $2.6-176$ & 0.6 & $<0.1-1.5$ & 0.2 & $<0.1-1.8$ \\
\hline Cadmium . . . . . . . . & .1 & .1 & .3 & $.1-51$ & 11.8 & $<.1-10$ & $1<.1$ & $<.1-.6$ \\
\hline Chromium ........ & 1 & .05 & 43 & $35-65$ & .2 & $<.05-.6$ & .4 & $<.05-.6$ \\
\hline Copper . . . . . . . . . & 1 & .5 & 26 & $18-1,250$ & 155 & $1.4-387$ & 11.4 & $1.0-2.1$ \\
\hline Lead . . . . . . . . & 1 & .1 & 42 & $12-6,600$ & .2 & $<.1-12$ & $<.1$ & $<.1-1.7$ \\
\hline Mercury .......... & .02 & .1 & .1 & $.2-5.5$ & .2 & $<.1-1.0$ & .2 & $.1-1.9$ \\
\hline Nickel. . . . . . . . . . & 2 & .1 & 18 & $12-24$ & $<.1$ & $<.1-.3$ & $<.1$ & $<.1-.3$ \\
\hline Selenium . . . . . . . & .1 & .1 & .2 & $.1-.9$ & 14.6 & $.4-24$ & 11 & $.6-1.8$ \\
\hline Zinc $\ldots \ldots \ldots \ldots$ & 2 & .5 & 98 & $46-6,133$ & 1104 & $9.0-294$ & 116 & $11-36$ \\
\hline
\end{tabular}

${ }^{1}$ Medians significantly different $(\mathrm{p}<0.05)$ between fish liver and fillet tissue.

order of magnitude higher in livers than in fillets (table 2).

Trace-element concentrations also can vary among species. Tissue of piscivorous species generally contains higher concentrations of $\mathrm{Hg}$ than does tissue of coexisting fish of lower trophic levels (Wiener and Spry, 1996). Hg concentrations in rainbow trout tissue have been found to be lower in muscle than in the liver and other organs, whereas concentrations in walleye (Stizostedion vitreum), carp (Cyprinus carpio), and largemouth bass (Micropterus salmoides) generally are highest in muscle tissue (Foster and others, 2000). It is apparent from these results that caution should be used when comparing tissue concentrations reported in other studies to those reported in this study, because results can vary depending on type of tissue and species analyzed.

Sites 1, 3, 4, 6, 10, 12, and 16 are considered enriched with trace elements relative to other sample sites on the basis of significant deposits (fig. 2, appen$\operatorname{dix} \mathrm{A})$. Another characteristic of these enriched sites is that mining densities generally are higher than at sites with no significant deposits.

Concentrations of $\mathrm{As}, \mathrm{Cd}, \mathrm{Cu}, \mathrm{Pb}, \mathrm{Hg}$, and $\mathrm{Zn}$ in bed sediment were highest at these enriched sites, whereas concentrations of trace elements in fish tissue generally did not show this same pattern (fig. 3). A few exceptions included higher $\mathrm{Cd}$ concentrations in liver tissue and the detection of $\mathrm{Pb}$ in fillet tissue only at enriched sites.

The South Fork Coeur d'Alene River near Pinehurst (site 12) contained the highest concentrations of $\mathrm{Cd}, \mathrm{Pb}, \mathrm{Hg}$, and $\mathrm{Zn}$ in bed sediment. This site also had the highest concentrations of $\mathrm{Cd}, \mathrm{Pb}$, and $\mathrm{Zn}$ in fish tissues. Some of these concentrations at this site exceeded the national median by several orders of magnitude. A pilot study by Krabbenhoft and others (1999), which consisted of 105 sampling sites nationwide, also reported the highest concentrations of total $\mathrm{Hg}$ (4.52 $\mu \mathrm{g} / \mathrm{g}$ ) in bed sediment at site 12 . This concentration is similar to the range of $\mathrm{Hg}$ concentrations (4.5 to 6.2 $\mu \mathrm{g} / \mathrm{g}$ ) in replicate samples collected at site 12 during this study. Concentrations of $\mathrm{Cu}$ in bed sediment from the upper Clark Fork (sites 1, 3, and 6) exceeded the national median. According to a report by Phillips and Lipton (1995), many of the past fish kills associated with mining activities in the upper Clark Fork have been caused primarily by $\mathrm{Cu}$ toxicity.

In the Clark Fork, concentrations of $\mathrm{As}, \mathrm{Cd}, \mathrm{Cu}$, $\mathrm{Pb}, \mathrm{Se}$, and $\mathrm{Zn}$ in bed sediment decreased from site 1 downstream to site 6 . This same decrease in concentrations of trace elements in bed sediment with distance from mining sources on the Clark Fork was observed by Andrews (1987). Deacon and Driver (1999) also reported a decrease in trace-element concentrations in bed sediments of Colorado streams with distance from mining source areas. This is the result of dilution by 
sediment from sources having lower concentrations of trace elements. Concentrations of $\mathrm{Cr}, \mathrm{Ni}$, and $\mathrm{Se}$ in bed sediments did not appear to be associated with traceelement-enriched sites.

Results of this study indicate that concentrations of some trace elements in bed sediment and liver tissue of fish from NROK streams generally are higher than national median concentrations in sediment and fish tissue determined from the NAWQA Program, 199296 (fig. 3). At one or more sites, $\mathrm{As}, \mathrm{Cd}, \mathrm{Cr}, \mathrm{Cu}, \mathrm{Pb}, \mathrm{Hg}$, $\mathrm{Se}$, and $\mathrm{Zn}$ in bed sediment exceeded national median concentrations. The median concentrations of $\mathrm{As}, \mathrm{Pb}$, and $\mathrm{Hg}$ in bed sediment samples from all NROK sites (table 2) exceeded national median concentrations (fig. 3). Similarly, $\mathrm{As}, \mathrm{Cd}, \mathrm{Cu}, \mathrm{Pb}, \mathrm{Hg}$, $\mathrm{Se}$, and $\mathrm{Zn}$ in fish liver samples from one or more sites exceeded national median concentrations (fig. 3). Median concentrations of $\mathrm{As}, \mathrm{Cd}, \mathrm{Cu}, \mathrm{Pb}, \mathrm{Hg}$, and $\mathrm{Se}$ in liver samples (table 2) also exceeded national median concentrations (fig. 3). The median concentration of $\mathrm{Zn}$ in liver samples was equal to the national median concentration $(104 \mu \mathrm{g} / \mathrm{g})$. It is worth noting that $\mathrm{Cr}, \mathrm{Ni}$, and $\mathrm{Se}$ concentrations in bed sediment and tissue were generally below national median concentrations, an indication that anthropogenic or natural sources for these trace elements may be more prevalent in other areas.

\section{Trace-Element Concentrations in Bed Sediment and Fish Tissue}

$\mathrm{As}, \mathrm{Cr}, \mathrm{Pb}$, and $\mathrm{Ni}$ concentrations were higher in bed sediments than in fish tissue at all sample sites (fig. 3). Heiny and Tate (1997) also noted that As, Cr, and $\mathrm{Pb}$ concentrations were higher in bed sediments than in fish livers. In addition, correlations between most trace-element concentrations in bed sediment and fish tissue (liver and fillet) were not significant $(\mathrm{r}< \pm 0.50, \mathrm{p}>0.05)$; however, the correlation between $\mathrm{Cd}$ concentrations in bed sediment and liver tissue was significant $(r=0.74, p<0.05)$. Because there are speciesspecific differences in trace-element tissue concentrations, a separate correlation analysis was performed only on liver samples of largescale suckers. These results also showed no significant correlations between bed sediment and liver tissue. Bonn (1999) and Heiny and Tate (1997) also noted poor correlations between most trace elements in bed sediment and fish tissue in a recent study of an Oregon river. Trace-element concentrations in bed sediment do not appear to be good pre- dictors of concentrations in fish tissue. The use of another bed sediment extraction method that determines bioavailable trace elements would perhaps strengthen this relation.

A comparison of the ratios of concentrations in tissue (liver and fillet) samples to those in bed sediment samples from the same sites illustrates those trace elements that tend to bioaccumulate. Liver and fillet tissue accumulated $\mathrm{Hg}$ and $\mathrm{Se}$ at higher concentrations than did bed sediment (ratio $>1$, fig. 4). Cd tended to accumulate in liver but not in fillet tissue. Ratios of median $\mathrm{Cu}$ and $\mathrm{Zn}$ concentrations in liver were near 1. Liver tissue accumulated all five of these trace elements, whereas fillet tissue accumulated only $\mathrm{Hg}$ and Se. Both $\mathrm{Hg}$ and $\mathrm{Se}$ are known to accumulate in muscle tissue of fish because these elements can be converted to bioavailable forms of organometallic compounds in bed sediment, which can be ingested and, thus, can accumulate in aquatic biota (Lemly, 1996; Weiner and Spry, 1996). The highest $\mathrm{Hg}$ concentration of $1.9 \mu \mathrm{g} / \mathrm{g}$ in fillets of brown trout from Rock Creek near Clinton, Mont. (site 2), were near the USEPA SV. Ratios of Se concentrations in liver tissue to those in bed sediment were among the highest of the trace-element ratios examined. Se concentrations of $24 \mu \mathrm{g} / \mathrm{g}$ in liver samples from sites 2 and 7 exceeded the toxic effects threshold of $12 \mu \mathrm{g} / \mathrm{g}$ for most freshwater fish (Lemly, 1996). Concentrations of Se above this threshold may affect fish health or reproductive success. Heiny and Tate (1997) also noted that Se concentrations were an order of magnitude higher in fish livers than in bed sediments in the South Platte River Basin in Colorado, Nebraska, and Wyoming. Other elements, such as As and $\mathrm{Pb}$, also form organometallic compounds, but these elements did not appear to accumulate in tissue. These findings are consistent with those reported for the Willamette River Basin (Wentz and others, 1998; Bonn, 1999). Although concentrations of $\mathrm{Pb}$ were high $(>100 \mu \mathrm{g} / \mathrm{g}$ ) in bed sediment at some NROK sites, $\mathrm{Pb}$ did not tend to accumulate in fish livers or fillets. This finding is particularly important because $\mathrm{Pb}$ has been identified as a pollutant of concern to humans and wildlife as a result of mining activities in this study area.

\section{Trace-Element Concentrations Reported in Other Studies and Guidelines}

The Canadian ISQG Probable Effect Levels (PELs), USEPA SVs, and NAWQA 1992-96 study 

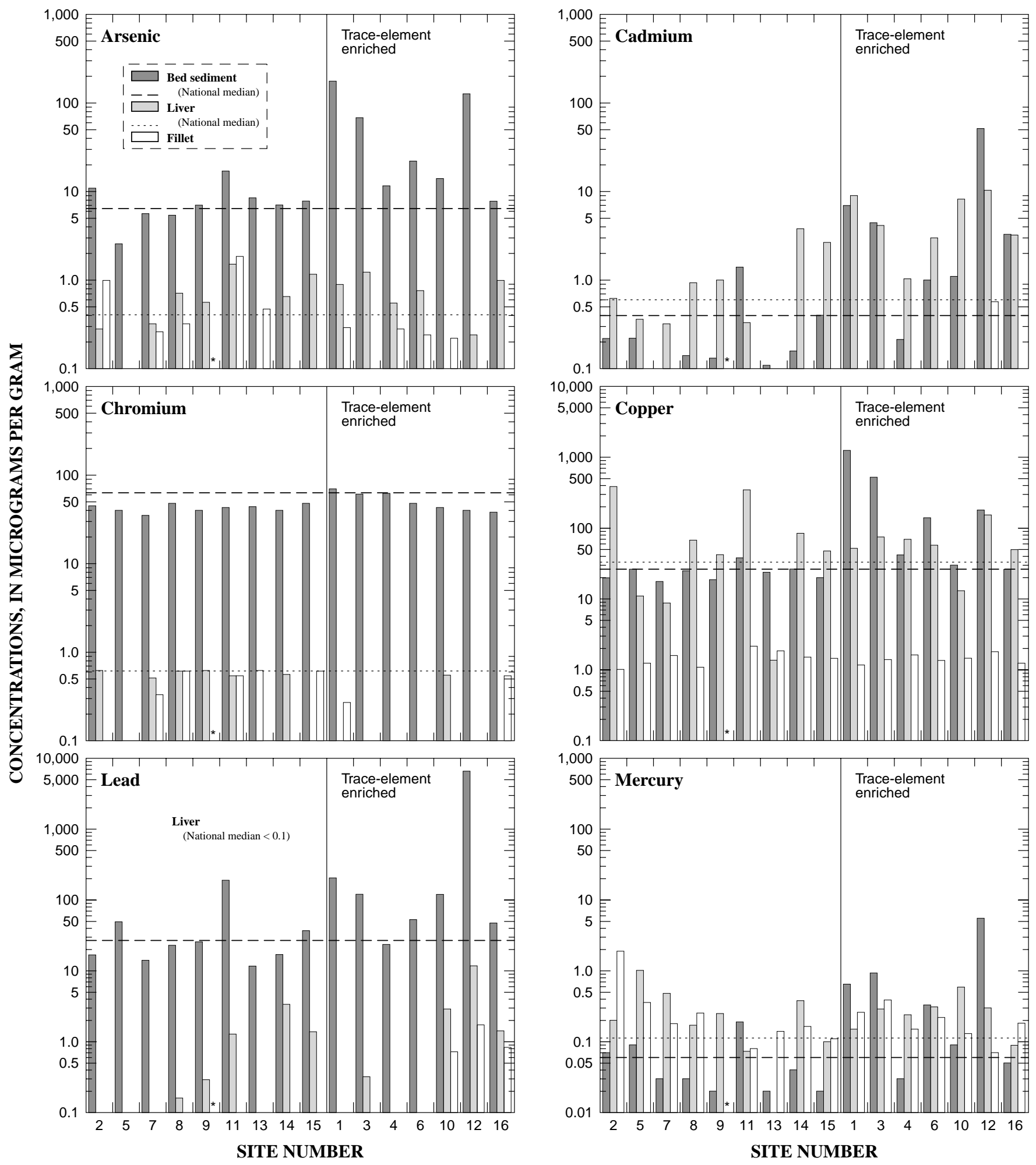

Figure 3. Trace-element concentrations in bed sediment and fish tissue (livers and fillets) at all sampling sites in the Northern Rockies Intermontane Basins study area. [Site names shown in table 1; locations shown in figure 1. Sites are grouped by the degree of trace-element enrichment from significant natural deposits (see figure 2). Dashed lines represent National WaterQuality Assessment Program median concentrations in bed sediment (number of samples, 541) and fish liver tissue (number of samples, 179) from across the Nation, 1992-96 (Rice, 1999; T. Short, U.S. Geological Survey, written commun., 1999). Asterisk indicates no sample collected. Blanks indicate trace element was not detected in fish tissue at that site] 

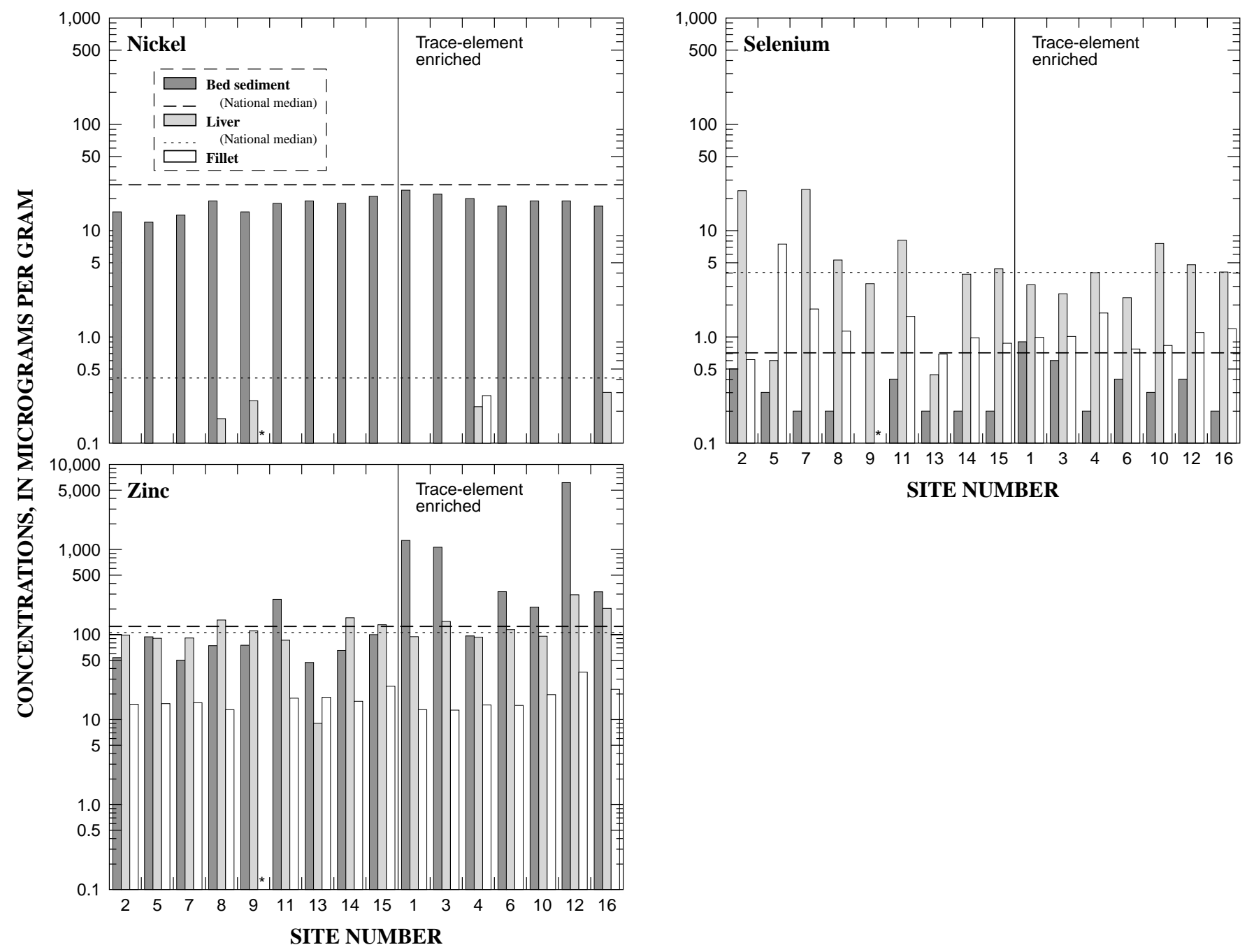

Figure 3. Trace-element concentrations in bed sediment and fish tissue (livers and fillets) at all sampling sites in the Northern Rockies Intermontane Basins study area-Continued.

results used to compare trace-element concentrations analyzed in this study are listed in table 3 . The PEL is defined as the concentration above which adverse effects to aquatic life are predicted to occur frequently. The USEPA SVs were used to compare concentrations in bed sediment and fish fillets and are defined as those at which "associated adverse effects to aquatic life or human health are possible, but expected infrequently" (U.S. Environmental Protection Agency, 1997).

Because no guidelines exist for fish liver tissue, the USGS NAWQA 85th percentile was used to evaluate whether liver tissue concentrations measured for this study were elevated.
Concentrations of $\mathrm{As}, \mathrm{Cd}, \mathrm{Cu}, \mathrm{Pb}, \mathrm{Hg}$, or $\mathrm{Zn}$ in bed sediment exceeded the PEL at sites 1, 3, 6, 10, 12, and 16 , which are associated with mining activities and (or) significant mineral deposits (fig. 2, table 3). Concentrations of one or more of these trace elements at 44 percent of the sites sampled exceeded levels at which adverse biological effects to aquatic biota could occur. This indicates potential problems with benthic organisms that provide an important food source for fish. Although this study did not address effects to stream biota directly, other studies have shown that adverse effects to aquatic biota can occur at sites in this study area that are downstream from mining activities. Sites at which trace-element concentrations most frequently 


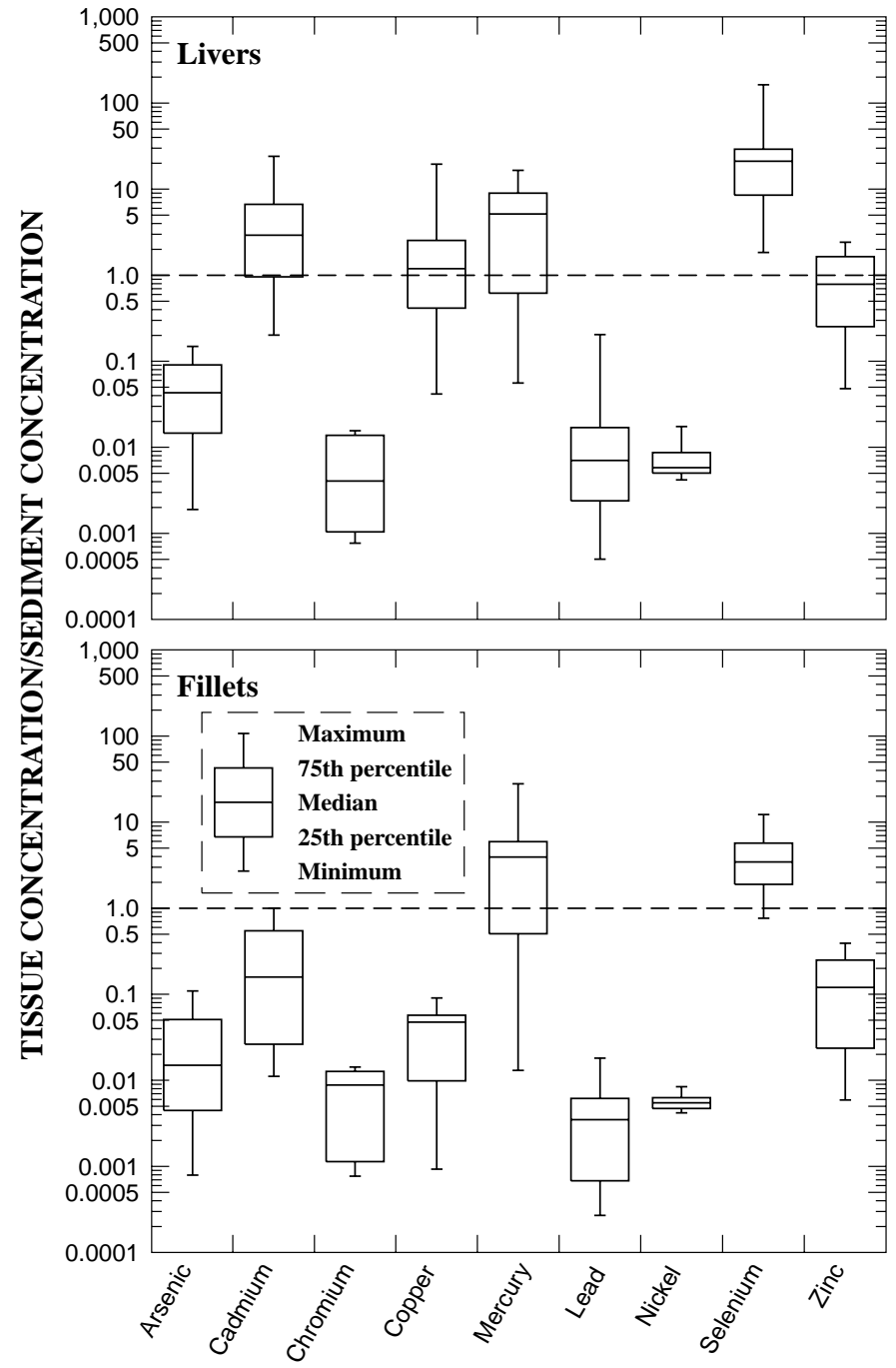

TRACE ELEMENT

Figure 4. Distribution of ratios of trace-element concentrations in fish tissue (livers and fillets) to concentrations in bed sediment, Northern Rockies Intermontane Basins study area. (Ratios for nondetections were calculated by substituting the minimum reporting level. Dashed line represents equal concentrations for tissue and bed sediment)

exceeded the PEL included the upper Clark Fork (sites 1 and 3) and the South Fork Coeur d'Alene River near Pinehurst (site 12). These sites are downstream from major past mining activities and Superfund sites. Concentrations of all trace elements except Se, for which no SV data are available at this time, exceeded USEPA SVs. However, no Se concentrations exceeded the toxicity threshold for sediment of $4 \mu \mathrm{g} / \mathrm{g}$, dry weight, established by the National Irrigation Water Quality Program for the protection of aquatic life (U.S. Department of the Interior, 1998). Concentrations of one or more trace elements exceeded the SV at 14 of 16 sites sampled; concentrations at sites 7 and 9 were the only exceptions.

On the basis of USEPA SVs, bed sediments in most of the NROK study area are enriched with trace elements. Both the USEPA SVs and the Canadian ISQG PELs are based on total concentration in bulk (total particle-size fraction) sediment, whereas all bed sediment samples in this study represent the <63-micron size fraction. Therefore, comparison of trace-element concentrations in this study with PELs may result in overestimating concentrations that adversely affect aquatic life. Deacon and Driver (1999) compared traceelement concentrations in the $<63$-micron size fraction and in bulk sediment samples from mining sites in Colorado. They noted that, although trace-element concentrations generally were higher in the smaller size fraction, concentrations overall were higher in samples from mined sites, regardless of the sediment size fraction analyzed.

Although many of the NROK sites exhibited traceelement enrichment, none of the trace-element concentrations in sportfish fillets exceeded USEPA SVs (table 3). This is noteworthy, because $\mathrm{Hg}$ and $\mathrm{Pb}$ can bioaccumulate in aquatic biota and are pollutants of concern around mining sites in the study area. According to Luoma (1983), the mechanisms of trace-element accumulation and storage in aquatic organisms are complex and diverse, varying with chemical form of the metal, mode of uptake, and species. It is apparent from this study that trace elements in bed sediment may not be readily bioavailable for uptake by some fish (fig. 4), especially the trace elements $\mathrm{As}, \mathrm{Cd}, \mathrm{Pb}, \mathrm{Hg}$, and $\mathrm{Se}$, which are known to bioaccumulate. Because bioavailability of trace elements was not specifically addressed in this study, reasons for this lack of bioavailability are unclear; however, the cause may be low concentrations of organic carbon in wetlands in the watersheds. Trace elements in such habitats can, through various processes, change to more bioavailable forms, such as methylation of $\mathrm{Hg}$ into methylmercury, which then are more easily incorporated into the aquatic food chain. In addition, the salmonid species analyzed in this study may be less likely to bioaccumulate some of these trace elements than are other more piscivorous species, such as walleye and largemouth bass.

Even though $\mathrm{Pb}$ is a known health risk to humans when ingested and has been found in fish tissue, no USEPA criteria or SVs exist. $\mathrm{Pb}$ was detected in fillet tissue samples only at sites 10,12, and 16, all located in the Spokane River Basin. The highest Pb concentra- 
Table 3. Comparison among various trace-element guidelines and concentrations detected in bed sediment and fish tissue, Northern Rockies Intermontane Basins study area

[ISQGs, Canadian Interim Sediment Quality Guidelines; PEL, Probable Effect Level; USEPA SV, U.S. Environmental Protection Agency screening values for bed sediment and edible tissue (fillets); NAWQA 85th percentile, National Water-Quality Assessment Program 85th percentile for fish livers. Concentrations are in micrograms per gram, dry weight; screening values for tissue were converted to dry weight by assuming a moisture content of 74 percent, which was the mean for fish sampled in this study; na, not available; see table 1 for site names and figure

1 for site locations]

\begin{tabular}{|c|c|c|c|c|c|c|c|c|}
\hline \multirow[b]{3}{*}{ Trace element } & \multicolumn{4}{|c|}{ Guidelines } & \multicolumn{4}{|c|}{$\begin{array}{c}\text { Sites with concentrations above } \\
\text { Canadian PEL; USEPA SV; NAWQA 85th percentile }\end{array}$} \\
\hline & \multirow{2}{*}{ 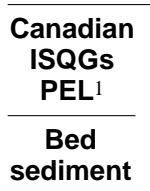 } & \multicolumn{2}{|c|}{ USEPA (SV) ${ }^{2}$} & \multirow{2}{*}{$\begin{array}{c}\begin{array}{c}\text { NAWQA } \\
\text { 85th } \\
\text { percentile }\end{array} \\
\begin{array}{c}\text { Fish } \\
\text { liver }\end{array}\end{array}$} & \multirow{2}{*}{$\begin{array}{c}\text { Canadian } \\
\text { ISQGs } \\
\text { PEL1 } \\
\text { Bed } \\
\text { sediment }\end{array}$} & \multicolumn{2}{|l|}{ USEPA(SV) } & \multirow{2}{*}{$\begin{array}{c}\text { NAWQA } \\
\text { 85th percentile3 } \\
\begin{array}{c}\text { Fish } \\
\text { liver }\end{array}\end{array}$} \\
\hline & & $\begin{array}{c}\text { Bed } \\
\text { sediment }\end{array}$ & $\begin{array}{l}\text { Fish } \\
\text { fillet }\end{array}$ & & & $\begin{array}{c}\text { Bed } \\
\text { sediment }\end{array}$ & $\begin{array}{l}\text { Fish } \\
\text { fillet }\end{array}$ & \\
\hline Arsenic . & 17 & 7.24 & 12 & 0.6 & $1,3,6,12$ & $\begin{array}{l}1,2,3,4,6,10,11,12 \\
13,15,16\end{array}$ & 0 & $1,3,6,8,11,15,16$ \\
\hline Cadmium.............. & 3.53 & .68 & 38 & 3.4 & $1,3,12$ & 11,12 & 0 & $1,3,10,12,14$ \\
\hline Chromium.............. & 90 & 52.3 & na & 1.0 & 0 & $1,3,4$ & na & 0 \\
\hline Copper.............. & 197 & 18.7 & na & 109 & 1,3 & $\begin{array}{l}1,2,3,4,5,6,8,10 \\
11,12,13,14,15,16\end{array}$ & na & $2,11,12$ \\
\hline Lead. . ............. & 91.3 & 30.2 & na & .3 & $1,3,1011,12$ & $\begin{array}{l}1,3,5,6,10,11,12 \\
15,16\end{array}$ & na & $3,10,11,12,14,15,16$ \\
\hline Mercury............... & .49 & .13 & 2.3 & .4 & $1,3,12$ & $1,3,6,11,12$ & 0 & $5,7,10$ \\
\hline Nickel $\ldots \ldots \ldots \ldots \ldots \ldots$ & 35.9 & 15.9 & na & 1.0 & 0 & $\begin{array}{l}1,3,4,6,8,10,11,12 \\
13,14,16\end{array}$ & na & 0 \\
\hline Selenium $\ldots \ldots \ldots \ldots \ldots$ & na & na & 192 & 7.1 & na & na & 0 & $2,7,10,11$ \\
\hline Zinc $\ldots \ldots \ldots \ldots \ldots \ldots$ & 315 & 124 & na & 469 & $1,3,6,12,16$ & $1,3,6,10,11,12,16$ & na & 0 \\
\hline
\end{tabular}

1 Canadian ISQG PELs are concentrations above which adverse effects to aquatic life are predicted to occur frequently (Canadian Council of Ministers of the Environment, 1995).

2 USEPA bed sediment SVs are defined as "associated adverse effects to aquatic life or human health are possible, but expected infrequently"; USEPA tissue SVs are for protection of human health, based on $1 \times 10^{-5}$ risk factor for an average-sized adult (70 kilograms) and a consumption rate of 6.5 grams of fish per day (U.S. Environmental Protection Agency, 1995, 1997).

3 85th percentile calculated from a total of 179 composite fish samples made up of 92 percent liver and 8 percent whole fish samples, 1992-96 (T. Short, U.S. Geological Survey, written commun., 1999). 
tion $(1.7 \mu \mathrm{g} / \mathrm{g})$ was observed in brook trout fillets from the South Fork Coeur d'Alene River near Pinehurst (site 12). This value is well below the International Legal Limit of $7.7 \mu \mathrm{g} / \mathrm{g}$, dry weight, established for removing fish from the marketplace to protect human health (Nauen, 1983).

One or more concentrations of $\mathrm{As}, \mathrm{Cd}, \mathrm{Cu}, \mathrm{Pb}, \mathrm{Hg}$, or Se in liver tissue at 13 of 16 sites exceeded the NAWQA Program 85th percentile (table 3). None of the $\mathrm{Cr}$, $\mathrm{Ni}$, or $\mathrm{Zn}$ concentrations in liver tissue exceeded this percentile.

\section{RELATIONS AMONG TRACE-ELEMENT CONCENTRATIONS, LAND USE, AND GEOLOGY}

Relations among trace-element concentrations in bed sediment and fish tissue and the landscape vari-

Table 4. Spearman's correlation coefficients for production mine densities, significant deposit densities, and trace-element concentrations in fish tissue (livers and fillets) and bed sediment, Northern Rockies Intermontane Basins study area

[Mine densities and significant deposits are given for the entire area upstream from each sample site (basin) and within a 250-meter buffer for all streams upstream from the sample site (buffer area). Significant coefficients shown in bold $(r> \pm 0.50, p<0.05)$; $n$, number of samples]

\begin{tabular}{|c|c|c|c|c|}
\hline $\begin{array}{l}\text { Sample type } \\
\text { and } \\
\text { trace element }\end{array}$ & $\begin{array}{l}\text { Production } \\
\text { mine density } \\
\text { (basin) }\end{array}$ & $\begin{array}{l}\text { Production } \\
\text { mine density } \\
\text { (buffer area) }\end{array}$ & $\begin{array}{c}\text { Significant } \\
\text { deposit density } \\
\text { (basin) }\end{array}$ & $\begin{array}{c}\text { Significant } \\
\text { deposit density } \\
\text { (buffer area) }\end{array}$ \\
\hline
\end{tabular}

Tissue

Liver $(\mathbf{n}=16)$

Arsenic ........................

Cadmium. . . . . . . . . . . . .

Chromium.............

Copper. . . . . . . . . . . . .

Lead. . . . . . . . . . . . .

Mercury.................

Nickel .................

Selenium .................

Zinc

Fillet $(n=15)$

Cadmium. . . . . . . . . . . . . .

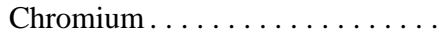

Copper.................

Lead. ...................

Mercury.................

Nickel .................

Selenium .................

Zinc

Bed sediment (n=16)

Arsenic .................. .

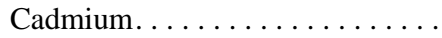

Chromium...............

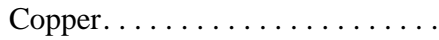

Lead. . . . . . . . . . . . . . . .

Mercury. ..............

Nickel .................

Selenium ................

Zinc.

0.33
.54
-.62
.41
.31
-.30
-.12
-.21
.07

$-0.01$

.42

$-.26$

.24

.36

$-.38$

.14

.19

.10

\section{.88}

.83

.30

.74

.77

.62

.67

.59

.81
0.03

.73

$-.71$

.07

.22

$-.13$

.06

$-.59$

.36

$-0.31$

.42

$-.21$

$-.05$

.43

$-.08$

.14

$-.03$

.01
0.04

.75

$-.62$

.22

.19

.09

.13

$-.26$

.30

$-0.22$

.45

$-.31$

.01

.49

$-.13$

.39

.19

$-.09$

\section{.66}

.61

.31

.62

.46

.39

.68

.35

.64 
ables of land use and geology were examined. No significant correlations between land use categories and trace-element concentrations in either bed sediment or fish tissue were apparent. There were also no significant correlations between geology and trace-element concentrations in fish tissue. However, there were a few significant correlations $(\mathrm{p}<0.05)$ between $\mathrm{Se}(\mathrm{r}=0.72)$ and $\mathrm{Hg}(\mathrm{r}=0.60)$ concentrations in bed sediment and percent sedimentary rock. Because these traditional landscape variables of land use and geology did not explain the differences observed in trace-element concentrations, other measures of trace-element enrichment were explored.

Because of the extent of mineralization in the NROK study area, natural conditions can affect traceelement concentrations in the environment. However, mining practices also can cause increased concentrations of trace elements (Axtmann and Luoma, 1991). Two measures of trace-element enrichment, production mine density and significant deposits, for each basin were examined in relation to trace-element concentrations in fish tissue and bed sediment (appendix A). Significant correlations $(r> \pm 0.50, \mathrm{p}<0.05)$ among the tissue types, bed sediment, and trace-element enrichment measures are listed in table 4. In general, the determination of production mine density and significant deposits within stream channel buffers did not improve the relation between landscape variables and trace-element concentrations in tissue or bed sediment.

$\mathrm{Cd}$ and $\mathrm{Cr}$ in liver tissue and $\mathrm{Pb}$ in fillet tissue were the only trace elements significantly correlated with mining measures of enrichment $(r> \pm 0.50, p<0.05)$. The negative correlations between $\mathrm{Cr}$ and measures of enrichment indicate that concentrations of this trace element in tissues are associated with something other than natural mineralization or mining. $\mathrm{Pb}$ in fillet tissue was correlated with significant deposits in the stream buffer but not with production mine density.

In bed sediment, all trace elements except $\mathrm{Cr}$ were significantly correlated with one or more mining measures of enrichment. Among all correlations between mining measures and trace-element concentrations in bed sediment, basinwide production mine density and $\mathrm{As}, \mathrm{Cd}, \mathrm{Cu}, \mathrm{Pb}$, and $\mathrm{Zn}$ correlations produced some of the highest coefficients $(r>0.70)$. Regression of mine density and the sum of the nine trace-element concentrations in bed sediment at each site (fig. 5) identified two statistically significant relations $\left(\mathrm{r}^{2}=0.95\right.$ and 0.99 , $\mathrm{p}<0.001)$ that respectively corresponded with the distinct groups of unenriched and enriched sites (fig. 2).
These strong relations warrant further study using mine density as an explanatory variable for trace-element concentrations in bed sediment.

Highest concentrations of $\mathrm{As}, \mathrm{Cd}, \mathrm{Cu}, \mathrm{Pb}$, and $\mathrm{Hg}$ (fig. 3) in sediment at sites located on the upper Clark Fork (sites 1, 3, and 6) and at South Fork Coeur d'Alene River near Pinehurst (site 12) corresponded to some of the highest production mine densities. Concentrations at these sites were 1 to 2 orders of magnitude higher than concentrations at most other sample sites. Concentrations at the least-enriched sites generally were between 100 and $200 \mu \mathrm{g} / \mathrm{g}$ (fig. 5), whereas concentrations at enriched sites ranged from about $300 \mu \mathrm{g} / \mathrm{g}$ (site 4) to more than 13,000 $\mu \mathrm{g} / \mathrm{g}$ (site 12).

Sites 11 and 12, both located on the South Fork Coeur d'Alene River, represent the most upstream and downstream locations in relation to the most numerous significant deposits and production mines (fig. 1, enlargement). Production mine density (three mines) for site 11 is depicted as high in figure 5 because of small basin size $\left(18 \mathrm{~km}^{2}\right)$, and there are no significant deposits upstream from this site. Mine density for site 12 is similar, but there are 24 significant deposits upstream from this site, and 12 of these deposits are within the 250-m stream buffer (appendix A).

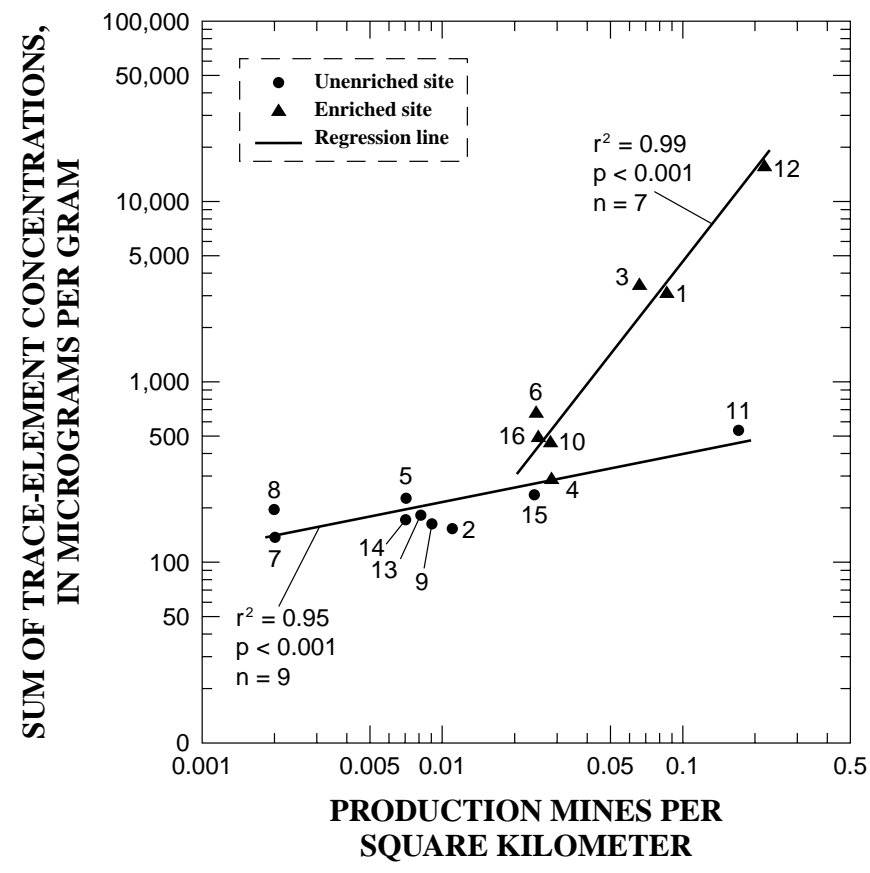

Figure 5. Relations between production mine density and sum of trace-element concentrations in bed sediment, Northern Rockies Intermontane Basins study area. [Sample sites are identified according to trace-element enrichment (table 1 and figure 2). 
Enrichment measures of significant deposits and production mine density generally were helpful for explaining the increased trace-element concentrations observed in bed sediment. In this study, however, enrichment resulting from natural mineralization and enrichment resulting from mining activities could not be differentiated. For future evaluations, if some sample sites could be found in basins that contain natural mineral deposits but are not influenced by past or current mining activities, trace-element concentrations in these two types of enriched areas could be compared.

\section{SUMMARY}

All nine trace elements evaluated for this report were detected in all bed sediment samples; however, not all trace elements were present above detection levels in fish tissue. Median concentrations of $\mathrm{Cd}, \mathrm{Cu}, \mathrm{Se}$, and $\mathrm{Zn}$ were significantly higher in liver tissue than in fillet tissue.

Sites $1,3,4,6,10,12$, and 16 are considered enriched with trace elements relative to other sample sites on the basis of significant deposits summarized for each basin. Concentrations of $\mathrm{As}, \mathrm{Cd}, \mathrm{Cu}, \mathrm{Pb}, \mathrm{Hg}$, and $\mathrm{Zn}$ in bed sediment were highest at these enriched sites. Concentrations of trace elements in fish tissue generally did not show this same pattern, except for high $\mathrm{Cd}$ concentrations in liver tissue and the detection of $\mathrm{Pb}$ in fillet tissue. Bed sediment from the South Fork Coeur d'Alene River contained the highest concentrations of $\mathrm{Cd}, \mathrm{Pb}, \mathrm{Hg}$, and $\mathrm{Zn}$. Fish tissue at this site also contained the highest concentrations of $\mathrm{Cd}, \mathrm{Pb}$, and $\mathrm{Zn}$. Some concentrations at this site exceeded the national median by several orders of magnitude. Concentrations of $\mathrm{Cu}$ in bed sediment from the upper Clark Fork exceeded the national median. Results from this study indicate that concentrations of some trace elements in bed sediment and liver tissue of fish from NROK streams generally are higher than national median concentrations in sediment and fish tissue determined from the NAWQA Program, 1992-96.

Correlations between most trace-element concentrations in bed sediment and tissue (livers and fillets) were poor; however, there was a significant correlation between $\mathrm{Cd}$ in bed sediment and liver tissue. Trace-element concentrations in bed sediment did not appear to be good predictors of concentrations in tissue.

Liver and fillet tissues accumulated $\mathrm{Cd}, \mathrm{Cu}, \mathrm{Hg}$, $\mathrm{Se}$, and $\mathrm{Zn}$ at higher concentrations than did bed sediment. All five of these elements were detected at high concentrations in liver tissue, whereas only $\mathrm{Hg}$ and $\mathrm{Se}$ were found at detectable levels in fillet tissue. Concentrations of Se in liver tissue relative to bed sediment were higher than any of the other four elements.

Although concentrations of $\mathrm{Pb}$ in bed sediment were high at some sites, $\mathrm{Pb}$ did not tend to accumulate in fish livers or fillets. This finding is particularly important because $\mathrm{Pb}$ has been identified as a pollutant of concern to humans and wildlife as a result of mining activities in this study area.

Concentrations of $\mathrm{As}, \mathrm{Cd}, \mathrm{Cu}, \mathrm{Pb}, \mathrm{Hg}$, or $\mathrm{Zn}$ in bed sediment exceeded the PEL primarily at sites associated with significant deposits and (or) mining activities. Concentrations of one or more of these trace elements at 44 percent of the sites sampled exceeded levels at which adverse biological effects to aquatic biota could occur. This indicates potential problems for the benthic organisms that provide an important food source for fish. Sites at which concentrations most frequently exceeded the PEL included the upper Clark Fork and the South Fork Coeur d'Alene River near Pinehurst, downstream from major past mining activities. Concentrations of one or more trace elements exceeded the SV at 14 of 16 sites sampled.

Even though many of the sites exhibited trace-element enrichment, no trace-element concentrations in sportfish fillets exceeded USEPA SVs. This is noteworthy, because $\mathrm{Pb}$ and $\mathrm{Hg}$ can bioaccumulate in aquatic biota and are pollutants of concern around mining sites in the study area. It is apparent from this study that trace elements in bed sediment are not readily bioavailable for uptake by fish, especially the trace elements $\mathrm{As}, \mathrm{Cd}, \mathrm{Pb}, \mathrm{Hg}$, and $\mathrm{Se}$, which are known to bioaccumulate in aquatic food chains. One or more concentrations of $\mathrm{As}, \mathrm{Cd}, \mathrm{Cu}, \mathrm{Pb}, \mathrm{Hg}$, or $\mathrm{Se}$ in liver tissue at 13 of 16 sites exceeded the NAWQA Program 85 th percentile.

No significant correlations between land use categories and trace-element concentrations in either bed sediment or fish tissue were apparent. There were also no meaningful significant correlations between geology and trace-element concentrations in fish tissue. Most trace-element concentrations in tissue did not correlate with significant deposits or production mine density. In bed sediment, all trace elements except $\mathrm{Cr}$ were significantly correlated with one or more mining measures of enrichment. Correlations between production mine density and $\mathrm{As}, \mathrm{Cd}, \mathrm{Cu}, \mathrm{Pb}$, and $\mathrm{Zn}$ produced some of the highest coefficients ( $r>0.70)$. Highest trace-element concentrations at sites located on the 
upper Clark Fork and South Fork Coeur d'Alene River corresponded to some of the highest production mine densities; concentrations were 1 to 2 orders of magnitude higher than at most other sample sites.

Regression of production mine density and the sum of trace-element concentrations in bed sediment identified two statistically significant relations $(\mathrm{r} 2=0.95$ and $0.99, \mathrm{p}<0.001)$ that respectively corresponded with the distinct groups of unenriched and enriched sites. These strong relations warrant further study using mine density as an explanatory variable to predict trace-element concentrations in bed sediment.

For future evaluations, if some sample sites could be found in basins that contain natural mineral deposits but are not influenced by past or current mining activities, trace-element concentrations in these two types of enriched areas could be compared.

\section{REFERENCES CITED}

Anderson, J.R., Hardy, E.E., Roach, J.T., and Witmer, R.E., 1976, A land use and land cover classification system for use with remote sensor data: U.S. Geological Survey Professional Paper 964, 28 p.

Andrews, E.D., 1987, Longitudinal dispersion of trace metals in the Clark Fork River, Montana, in Averett, R.C., and McKnight, D.M., eds., Chemical quality of water and the hydrologic cycle: Chelsea, Mich., Lewis Publishers, p. 179-191.

Arbogast, B.F., 1990, Quality assurance manual for the Branch of Geochemistry: U.S. Geological Survey Open-File Report 90-668, 184 p.

Axtmann, E.V., and Luoma, S.N., 1991, Large-scale distribution of metal contamination in the finegrained sediments of the Clark Fork River, Montana, USA: Applied Geochemistry, v. 6, p. $75-88$.

Beckwith, M.A., 1998, Concepts for monitoring water quality in the Spokane River Basin, north Idaho and eastern Washington: U.S. Geological Survey Open-File Report 98-534, 25 p.

Bonn, B.A., 1999, Selected elements and organic chemicals in bed sediment and fish tissue of the Tualatin River Basin, Oregon, 1992-96: U.S. Geological Survey Water-Resources Investigations Report 99-4107, 61 p.

Briggs, P.H., and Meier, A.L., 1999, The determination of forty-two elements in geological materials by inductively coupled plasma-mass spectrometry, in Arbogast, B.F., ed., Analytical methods manual for the Mineral Resource Surveys Program: U.S. Geological Survey Open-File Report 96-525, p. 76-88.

Canadian Council of Ministers of the Environment, 1995, Interim sediment quality guidelines: Soil and Sediment Quality Section Guidelines Division, Evaluation and Interpretation Branch Ecosystem Conservation Directorate, $65 \mathrm{p}$.

Crawford, J.K., and Luoma, S.N., 1993, Guidelines for studies of contaminants in biological tissue for the National Water-Quality Assessment Program: U.S. Geological Survey Open-File Report 92-494, 69 p.

Deacon, J.R., and Driver, N.E., 1999, Distribution of trace elements in streambed sediment associated with mining activities in the Upper Colorado River Basin, Colorado, USA, 1995-96: Archives of Environmental Contamination and Toxicology, v. 37 , p. $7-18$.

Doppelt, R., Scurlock, M., Frissell, C.A., and Karr, J.R., 1993, Entering the watershed-a new approach to save America's river ecosystems: Washington, D.C., Island Press, 462 p.

Eisler, R., 1985, Cadmium hazards to fish, wildlife, and invertebrates, a synoptic review: U.S. Fish and Wildlife Service Biological Report 85 (1.2), 46 p. 1987, Mercury hazards to fish, wildlife, and invertebrates, a synoptic review: U.S. Fish and Wildlife Service Biological Report 85 (1.10), $90 \mathrm{p}$.

1988, Lead hazards to fish, wildlife, and invertebrates, a synoptic review: U.S. Fish and Wildlife Service Biological Report 85 (1.14), 134 p.

Farag, A.M., Boese, C.J., Woodward, D.F., and Bergman, H.L., 1994, Physiological changes and tissue metal accumulation in rainbow trout exposed to foodborne and waterborne metals: Environmental Toxicology and Chemistry, v. 13, no. 12, p. 2021-2029.

Foster, E.P., Drake, D.L., and DiDomenico, G., 2000, Seasonal changes and tissue distribution of mercury in largemouth bass (Micropterus salmoides) from Dorena Reservoir, Oregon: Archives of Environmental Contamination and Toxicology, v. 38, p. 78-82.

Goldstein, R.M., Brigham, M.E., and Stauffer, J.C., 1996, Comparison of mercury concentrations in liver, muscle, whole bodies, and composites of fish from the Red River of the North: Canadian 
Journal of Fisheries and Aquatic Sciences, v. 53, p. 244-252.

Gurtz, M.E., 1994, Design of biological components of the National Water-Quality Assessment (NAWQA) Program, in Loeb, S.L., and Spacie, Anne, eds., Biological monitoring of aquatic systems: Boca Raton, Fla., Lewis Publishers, p. 323-354.

Heiny, J.S., and Tate, C.M., 1997, Concentration, distribution, and comparison of selected trace elements in bed sediment and fish tissue in the South Platte River Basin, USA, 1992-1993: Archives of Environmental Contamination and Toxicology, v. 32, p. 246-259.

Hirsch, R.M., Alley, W.M., and Wilber, W.G., 1988, Concepts for a National Water-Quality Assessment Program: U.S. Geological Survey Circular 1021, $42 \mathrm{p}$.

Hoffman, G.L., 1996, Methods of analysis by the U.S. Geological Survey National Water Quality Laboratory - preparation procedure for aquatic biological material determined for trace metals: U.S. Geological Survey Open-File Report 96-362, $42 \mathrm{p}$.

Hornberger, M.I., Lambing, J.H., Luoma, S.N., and Axtmann, E.V., 1997, Spatial and temporal trends of trace metals in surface water, bed sediment, and biota of the upper Clark Fork Basin, Montana: U.S. Geological Survey Open-File Report 97-669, $84 \mathrm{p}$.

Horowitz, A.J., 1991, A primer on sediment-trace element chemistry (2d ed.): Boca Raton, Fla., Lewis Publishers, $136 \mathrm{p}$.

Horowitz, A.J., Elrick, K.A., Robbins, J.A., and Cook, R.B., 1995, A summary of the effects of mining and related activities on the sediment-trace element geochemistry of Lake Coeur d'Alene, Idaho, USA: Journal of Geochemical Exploration, v. 52, p. 135-144.

Kendy, E., and Tresch, R.E., 1996, Geographic, geologic, and hydrologic summaries of intermontane basins of the Northern Rocky Mountains, Montana: U.S. Geological Survey Water-Resources Investigations Report 96-4025, 233 p.

Krabbenhoft, D.P., Wiener, J.G., Brumbaugh, W.G., Olson, M.L., DeWild, J.F., and Sabin, T.J., 1999, A national pilot study of mercury contamination of aquatic ecosystems along multiple gradients, in U.S. Geological Survey Toxic Substances Hydrology Program-Proceedings of the Tech- nical Meeting, Charleston, S.C., March 8-12, 1999: U.S. Geological Survey Water-Resources Investigations Report 99-4018-B, v. 2, p. 147-160.

Law, R.J., 1996, Metals in marine mammals, in Beyer, W.N., Heinz, G.H., and Redmon-Norwood, A.W., eds., Environmental contaminants in wildlife: Boca Raton, Fla., CRC Press, p. 357-376.

Leahy, P.P., Rosenshein, J.S., and Knopman, I.J., 1990, Implementation plan for the National WaterQuality Assessment Program: U.S. Geological Survey Open-File Report 90-174, 10 p.

Lemly, A.D., 1996, Selenium in aquatic organisms, in Beyer, W.N., Heinz, G.H., and Redmon-Norwood, A.W., eds., Environmental contaminants in wildlife: Boca Raton, Fla., CRC Press, p. 427-445.

Long, K.R., DeYoung, J.H., and Ludington, S.D., 1998, Database of significant deposits of gold, silver, copper, lead, and zinc in the United States: U.S. Geological Survey Open-File Report 98206-B, 33 p., 1 disk.

Lowe, T.P., May, T.W., Brumbaugh, W.G., and Kane, D.A., 1985, National contaminant biomonitoring program-concentrations of seven elements in freshwater fish, 1978-1981: Archives of Environmental Contamination and Toxicology, v. 14, p. 363-388.

Luoma, S.N., 1983, Bioavailability of trace metals to aquatic organisms: Science of the Total Environment, v. 28, p. 1-22.

Maret, T.R., and Dutton, D.M., 1999, Summary of information on synthetic organic compounds and trace elements in tissue of aquatic biota, Clark Fork-Pend Oreille and Spokane River Basins, Montana, Idaho, and Washington, 1974-96: U.S. Geological Survey Water-Resources Investigations Report 98-4254, 55 p.

Meador, M.R., Cuffney, T.E., and Gurtz, M.E., 1993, Methods for sampling fish communities as part of the National Water-Quality Assessment Program: U.S. Geological Survey Open-File Report 93-104, $40 \mathrm{p}$.

Moore, J.N., and Luoma, S.N., 1990, Hazardous wastes from large-scale metal extraction-a case study: Environmental Science and Technology, v. 24, p. $1278-1285$.

Natural Resource Defense Council, 1998, Contaminated catch, the public health threat from toxics in fish: accessed August 18, 2000, at URL http://www.nrdc.org/nrdcpro/catch/ccsum.html 
Nauen, C.E., 1983, Compilation of legal limits for hazardous substances in fish and fishery products: Rome, Food and Agricultural Organization of the United Nations, Circular 764, 102 p.

Park, J.G., and Curtis, L.R., 1997, Mercury distribution in sediments and bioaccumulation by fish in two Oregon reservoirs-point-source and nonpointsource impacted systems: Archives of Environmental Contamination and Toxicology, v. 33, p. 423-429.

Phillips, G., and Lipton, J., 1995, Injury to aquatic resources caused by metals in Montana's Clark Fork River basin-historic perspective and overview: Canadian Journal of Fisheries and Aquatic Sciences, v. 52, p. 1990-1993.

Rainbow, P.S., 1996, Heavy metals in aquatic invertebrates, in Beyer, W.N., Heinz, G.H., and Redmon-Norwood, A.W., eds., Environmental contaminants in wildlife: Boca Raton, Fla., CRC Press, p. 405-426.

Rice, K.C., 1999, Trace-element concentrations in streambed sediment across the conterminous United States: Environmental Science and Technology, v. 33, no. 15, p. 2499-2504.

Shelton, L.R., and Capel, P.D., 1994, Guidelines for collecting and processing samples of streambed sediment for analysis of trace elements and organic contaminants for the National WaterQuality Assessment Program: U.S. Geological Survey Open-File Report 94-458, 20 p.

Sorensen, E.M., 1991, Metal poisoning in fish: Boca Raton, Fla., CRC Press, 374 p.

Tornes, L.H., 1997, National Water-Quality Assessment Program-Northern Rockies Intermontane Basins: U.S. Geological Survey Fact Sheet FS158-97, 4 p.

Tuck, L.K., Briar, D.W., and Clark, D.W., 1996, Geologic history and hydrogeologic units of intermontane basins of the Northern Rocky Mountains, Montana and Idaho: U.S. Geological Survey Hydrologic Investigations Atlas HA-738-A, 1 sheet, scale 1:750,000.

U.S. Bureau of Mines, 1995, Minerals availability system: U.S. Geological Survey Special Publication 12-95 (data set on CD-ROM).

U.S. Department of the Interior, 1998, Guidelines for interpretation of the biological effects of selected constituents in biota, water, and sediment: National Irrigation Water Quality Program Information Report 3, 198 p.
U.S. Environmental Protection Agency, 1994, Water quality standards handbook ( 2 d ed.): U.S. Environmental Protection Agency, EPA-823-B-94005-B, appendix P.

1992, National study of chemical residues in fish, v. 1: Washington, D.C., U.S. Environmental Protection Agency, Office of Science and Technology, EPA 823-R-92-008-A.

1995, Guidance for assessing chemical contaminant data for use in fish advisories, v. 1, Fish sampling and analysis ( $2 \mathrm{~d}$ ed.): Washington, D.C., U.S. Environmental Protection Agency, Office of Water, EPA 823-R-95-007.

1997, The incidence and severity of sediment contamination in surface waters of the United States, v. 1-3: Washington, D.C., U.S. Environmental Protection Agency, Office of Water, EPA 823-R-97-006, -007, and -008.

U.S. Forest Service and Bureau of Land Management, 1998, Interior Columbia basin ecosystem management project: accessed August 18, 2000, at URL http://www.icbemp.gov

U.S. Geological Survey, 1986, Land use and land cover digital data from 1:250,000- and 1:100,000-scale maps, data users guide 4: Reston, Va., U.S. Geological Survey, $36 \mathrm{p}$.

Van Meter, W.P., 1974, Heavy metal concentration in fish tissue of the upper Clark Fork River: Bozeman, Mont., University Joint Water Resources Research Center Report 55, Completion Report Projects A-044 MONT and A-053 MONT, 37 p.

Wentz, D.A., Waite, I.R., and Rinella, F.A., 1998, Comparison of streambed sediment and aquatic biota as media for characterizing trace elements and organochlorine compounds in the Willamette Basin, Oregon: Environmental Monitoring and Assessment, v. 51, p. 673-693.

Wiener, J.G., and Spry, D.J., 1996, Toxicological significance of mercury in freshwater fish, in Beyer, W.N., Heinz, G.H., and Redmon-Norwood, A.W., eds., Environmental contaminants in wildlife: Boca Raton, Fla., CRC Press, p. 265-279.

Wilkinson, L., 1998, SYSTAT for Windows-statistics, version 8.0: Evanston, Ill., SYSTAT, Inc., 1086 p.

Woodward, D.F., Brumbaugh, W.G., DeLonay, A.J., Little, E.E., and Smith, C.E., 1994, Effects on rainbow trout fry of a metals-contaminated diet of benthic invertebrates from the Clark Fork River, Montana: Transactions of the American Fisheries Society, v. 123, p. 51-62. 



\section{SUPPLEMENTAL INFORMATION}



Appendix A. Hard-rock mining activities in the Northern Rockies Intermontane Basins study area and within a 250-meter buffer area along perennial streams in each subbasin

[Production mines are locations where active and past mineral commodities were extracted. Sand and gravel mines are not included. Data were taken from the Minerals Availability System, compiled by the U.S. Bureau of Mines (1995). Significant mineral deposits of the United States, including gold, silver, copper, lead, and zinc, were identified in the U.S. Geological Survey data base (Long and others, 1998); No., number; $\mathrm{km}^{2}$, square kilometers; m, meters]

\begin{tabular}{|c|c|c|c|c|c|c|c|c|c|}
\hline \multirow[b]{2}{*}{$\begin{array}{l}\text { Site } \\
\text { No. }\end{array}$} & \multirow[b]{2}{*}{$\begin{array}{l}\text { Predominant } \\
\text { commodities } \\
\text { mined }\end{array}$} & \multicolumn{4}{|c|}{ Basin } & \multicolumn{4}{|c|}{ Buffer $(250 \mathrm{~m})$} \\
\hline & & $\begin{array}{l}\text { Production } \\
\text { mines } \\
(1,353)^{\mathrm{a}}\end{array}$ & $\begin{array}{l}\text { Production } \\
\text { mines } / \mathbf{k m}^{2}\end{array}$ & $\begin{array}{l}\text { Significant } \\
\text { deposits } \\
(66)^{\mathrm{a}}\end{array}$ & $\begin{array}{c}\begin{array}{c}\text { Significant } \\
\text { deposits } / \mathbf{k m}^{2}\end{array}\end{array}$ & $\begin{array}{l}\text { Production } \\
\text { mines } \\
(660)^{\mathrm{b}}\end{array}$ & $\begin{array}{l}\text { Production } \\
\text { mines } / \mathbf{k m}^{2}\end{array}$ & $\begin{array}{c}\text { Significant } \\
\text { deposits } \\
(31)^{\mathrm{b}}\end{array}$ & $\begin{array}{c}\begin{array}{c}\text { Significant } \\
\text { deposits } / \mathbf{k m}^{2}\end{array}\end{array}$ \\
\hline 1 & Manganese, gold, silver. . . . . . & 149 & 0.0860 & 6 & 0.0030 & 42 & 0.0590 & 2 & 0.0028 \\
\hline 2 & Gold, silver, sapphires . . . . . . . & 20 & .0090 & 1 & .0004 & 11 & .0120 & 0 & 0 \\
\hline 3 & Gold, manganese, silver. . . . . . & 433 & .0450 & 20 & .0021 & 186 & .0500 & 7 & .0019 \\
\hline 4 & Gold, lead, silver . . . . . . . . & 36 & .0290 & 7 & .0056 & 23 & .0380 & 6 & .0098 \\
\hline 5 & Gold, silver, copper . . . . . . . & 51 & .0070 & 0 & 0 & 27 & .0100 & 0 & 0 \\
\hline 6 & Gold, silver, copper . . . . . . . . . & 666 & .0240 & 31 & .0011 & 333 & .0300 & 14 & .0013 \\
\hline 7 & Copper, coal. ............. & 5 & .0020 & 0 & 0 & 0 & 0 & 0 & 0 \\
\hline 8 & Copper, gold, silver . . . . . . . & 50 & .0020 & 1 & .0001 & 21 & .0020 & 0 & 0 \\
\hline 9 & Lead, silver, gold . . . . . . . . & 19 & .0080 & 0 & 0 & 13 & .0140 & 0 & 0 \\
\hline 10 & Lead, gold, silver . . . . . . . . & 62 & .0270 & 5 & .0022 & 28 & .0330 & 4 & .0046 \\
\hline 11 & Copper, lead, silver . . . . . . . . & 3 & .1680 & 0 & 0 & 0 & 0 & 0 & 0 \\
\hline 12 & Lead, silver, gold . . . . . . & 172 & .2330 & 24 & .0325 & 102 & .4170 & 12 & .0490 \\
\hline 13 & Gold, copper. . . . . . . . . . . & 3 & .0110 & 0 & 0 & 3 & .0340 & 0 & 0 \\
\hline 14 & Gold, copper, lead . . . . . . & 18 & .0070 & 0 & 0 & 13 & .0140 & 0 & 0 \\
\hline 15 & Stone, clay, tungsten . . . . . . . . & 42 & .0240 & 0 & 0 & 31 & .0260 & 0 & 0 \\
\hline 16 & Lead, stone, silver . . . . . . . & 349 & .0270 & 29 & .0022 & 182 & .0400 & 16 & .0035 \\
\hline
\end{tabular}

Total number in study area upstream from site 16.

b Total number in study area stream buffers upstream from site 16 
Appendix B. Species, sizes, and tissue types of fish collected in the Northern Rockies Intermontane Basins study area, 1998

[Site locations shown in figure 1; names shown in table 1; No., number; mm, millimeters; g, grams]

\begin{tabular}{|c|c|c|c|c|c|c|}
\hline $\begin{array}{l}\text { Site } \\
\text { No. }\end{array}$ & Species & $\begin{array}{c}\text { Tissue } \\
\text { type }\end{array}$ & $\begin{array}{l}\text { No. } \\
\text { of } \\
\text { fish }\end{array}$ & $\begin{array}{l}\text { Total } \\
\text { length } \\
(\mathrm{mm})\end{array}$ & $\begin{array}{c}\text { Mean } \\
\text { length } \\
(\mathrm{mm})\end{array}$ & $\begin{array}{l}\text { Weight } \\
\text { (g) }\end{array}$ \\
\hline \multirow[t]{3}{*}{1} & Largescale sucker. . . . . . . . . . & liver & 8 & $428-615$ & 512 & $724-2,247$ \\
\hline & Mountain whitefish . ......... & fillet & 5 & $350-412$ & 386 & $453-744$ \\
\hline & Brown trout $\ldots \ldots \ldots \ldots \ldots \ldots$ & fillet & 5 & $376-426$ & 400 & $463-751$ \\
\hline \multirow[t]{2}{*}{2} & Brown trout ${ }^{\mathrm{a}} \ldots \ldots \ldots \ldots \ldots$ & liver & 7 & $352-478$ & 410 & $451-903$ \\
\hline & Brown trout ${ }^{\mathrm{a}} \ldots \ldots \ldots \ldots \ldots$ & fillet & 7 & $352-478$ & 410 & $451-903$ \\
\hline \multirow[t]{4}{*}{3} & Largescale sucker. . . . . . . . . & liver & 8 & $422-531$ & 451 & $701-1,236$ \\
\hline & Largescale sucker........... & liver & 8 & $440-536$ & 477 & $776-1,446$ \\
\hline & Largescale sucker. . . . . . . . . & liver & 8 & $430-520$ & 481 & $769-1,423$ \\
\hline & Mountain whitefish . ......... & fillet & 6 & $325-376$ & 350 & $398-602$ \\
\hline \multirow[t]{2}{*}{4} & Largescale sucker. . . . . . . . . & liver & 8 & $407-551$ & 467 & $712-1,865$ \\
\hline & Mountain whitefish . ........ & fillet & 4 & $260-335$ & 282 & $154-382$ \\
\hline \multirow[t]{2}{*}{5} & Mountain whitefisha.......... & fillet & 8 & $280-340$ & 318 & $206-410$ \\
\hline & Mountain whitefisha.......... & liver & 17 & $280-350$ & 317 & $206-437$ \\
\hline \multirow[t]{2}{*}{6} & Largescale sucker........... & liver & 6 & $440-580$ & 505 & $1,021-1,971$ \\
\hline & Mountain whitefish . ......... & fillet & 5 & $310-385$ & 331 & $252-555$ \\
\hline \multirow[t]{3}{*}{7} & Mountain whitefish ${ }^{\mathrm{a}} \ldots \ldots \ldots \ldots$ & liver & 8 & $295-404$ & 337 & $224-536$ \\
\hline & Mountain whitefish ${ }^{\mathrm{a}} \ldots \ldots \ldots \ldots$ & fillet & 8 & $295-404$ & 337 & $224-536$ \\
\hline & Mountain whitefish ${ }^{\mathrm{a}} \ldots \ldots \ldots \ldots$ & fillet & 8 & $295-404$ & 337 & $224-536$ \\
\hline \multirow[t]{2}{*}{8} & Largescale sucker. . . . . . . . . & liver & 6 & $445-490$ & 463 & $943-1,411$ \\
\hline & Mountain whitefish .......... & fillet & 6 & $270-330$ & 303 & $189-308$ \\
\hline 9 & Largescale sucker. . . . . . . . . & liver & 8 & $375-468$ & 428 & $448-680$ \\
\hline \multirow[t]{2}{*}{10} & Mountain whitefish ${ }^{\mathrm{a}} \ldots \ldots \ldots \ldots$ & liver & 7 & $282-415$ & 332 & $235-832$ \\
\hline & Mountain whitefish ${ }^{\mathrm{a}} \ldots \ldots \ldots \ldots$ & fillet & 7 & $282-415$ & 332 & $235-832$ \\
\hline \multirow[t]{2}{*}{11} & Rainbow trouta, $\ldots \ldots \ldots \ldots \ldots$ & liver & 7 & $250-330$ & 300 & $168-437$ \\
\hline & Rainbow trout ${ }^{\mathrm{a}, \mathrm{b}}$. & fillet & 7 & $250-330$ & 300 & $168-437$ \\
\hline \multirow[t]{2}{*}{12} & Brook trout ${ }^{\mathrm{a}} \ldots$ & liver & 6 & $215-325$ & 298 & $141-425$ \\
\hline & Brook trout $^{\mathrm{a}} \ldots \ldots \ldots$ & fillet & 6 & $215-325$ & 298 & $141-425$ \\
\hline \multirow[t]{2}{*}{13} & Cutthroat trout $^{\mathrm{a}} \ldots \ldots$ & liver & 8 & $261-374$ & 322 & $185-567$ \\
\hline & Cutthroat trout $^{\mathrm{a}} \ldots \ldots \ldots \ldots \ldots$ & fillet & 8 & $261-374$ & 322 & $185-567$ \\
\hline \multirow[t]{2}{*}{14} & Largescale sucker............ & liver & 8 & $445-540$ & 485 & $823-1,487$ \\
\hline & Mountain whitefish . ......... & fillet & 8 & $210-324$ & 292 & $212-311$ \\
\hline \multirow[t]{2}{*}{15} & Largescale sucker............ & liver & 8 & $365-497$ & 445 & $470-1,330$ \\
\hline & Rainbow trout $\ldots \ldots \ldots \ldots \ldots$ & fillet & 5 & $225-260$ & 239 & $123-235$ \\
\hline \multirow[t]{2}{*}{16} & Largescale sucker............ & liver & 8 & $430-500$ & 471 & $795-1,160$ \\
\hline & Rainbow trout $\ldots \ldots \ldots \ldots \ldots$ & fillet & 5 & $330-460$ & 366 & $394-947$ \\
\hline
\end{tabular}

a Same fish used for analysis.

b Hatchery fish. 
